\title{
Late Weichselian landscape development and human settlement in Mecklenburg-Vorpommern (NE Germany)
}

\author{
Thomas Terberger, Pim De Klerk, Henrik Helbig, Knut Kaiser \& Peter Kühn*) \\ Dedicated to Prof. Dr. Konrad Billwitz on the occasion of his 65th birthday
}

Keywords: Late Weichselian, NE Germany, landscape development, palaeoecology, human settlement

\begin{abstract}
This paper presents the results of recent studies on the Weichselian Lateglacial in Mecklenburg-Vorpommern (NE Germany). The development of basins and valleys is illustrated with some examples. Soil formation could be demonstrated for the transition Pleniglacial-Lateglacial, the Allerød, and the Early Younger Dryas. Aeolian processes occurred predominantly during the Younger Dryas, whereas formation of cryogenic soil features is inferred for the colder periods of the Lateglacial. Detailed palynological analyses cover the complete Lateglacial and allow a reconstruction of the vegetation in relation to climate. Archaeological findings give information on the development of the fauna and on human settlement. Finally an integrated model of landscape development is presented.
\end{abstract}

"Anschrift der Verfasser: PD Dr. Thomas Terberger, Lehrstuhl für Ur- und Frühgeschichte, Ernst-MoritzArndt-Universität, Hans-Fallada-Straße 1, D-17487 Greifswald, Germany, terberge@uni-greifswald.de; Dr. Pim De Klerk, Botanisches Institut, ErnstMoritz-Arndt-Universität, Grimmerstraße 88, D17487 Greifswald, Germany; Dr. Henrix HeLbig, Landesamt für Geologie und Bergwesen SachsenAnhalt, Köthener Straße 34, D-06118 Halle (Saale), Germany; Dr. KnUt KaIser, Fachbereich Geographie, Universität Marburg, Deutschhausstraße 10, D35032 Marburg; Dr. Peter KüHN, Institut für Bodenkunde und Bodenerhaltung, Justus-LiebigUniversität, Heinrich-Buff-Ring 26 (IFZ), D-35392 Giessen, Germany
1. Introduction (TT, PdK)

2. Sedimentation processes, geomorphological development and soil formation

2.1 Deglaciation and development of basins and river valleys $(\mathrm{KK})$

2.2 Relic cryogenic macrofeatures/ Periglacial phenomena ( $\mathrm{HH}, \mathrm{PK})$

2.3 Aeolian processes (KK)

2.4 Soil formation (PK, KK, HH)

3. Vegetation history and palaeoclimate (PdK)

4. Development of the fauna (TT)

5. Human settlement (TT)

6. Integrated summary

\section{Introduction}

Research into Lateglacial landscape development and archaeology in the Federal State Mecklenburg-Vorpommern (NE Germany) made some major progress during the last years, partly within the framework of a large priority program of the Deutsche Forschungsgemeinschaft (DFG: German Research Council; cf. ANDRes \& LitT 1999; LitT 2003). It was possible to develop a new picture of the Lateglacial landscape development by means of detailed geomorphological, palaeohydrological, palynological and soil-scientific research of different study areas (cf. Fig. 1); in some cases geoscientific research was connected directly with archaeological field work. Numerous corings, as well as extensive observations and analyses of excavated soil profiles and open trenches 


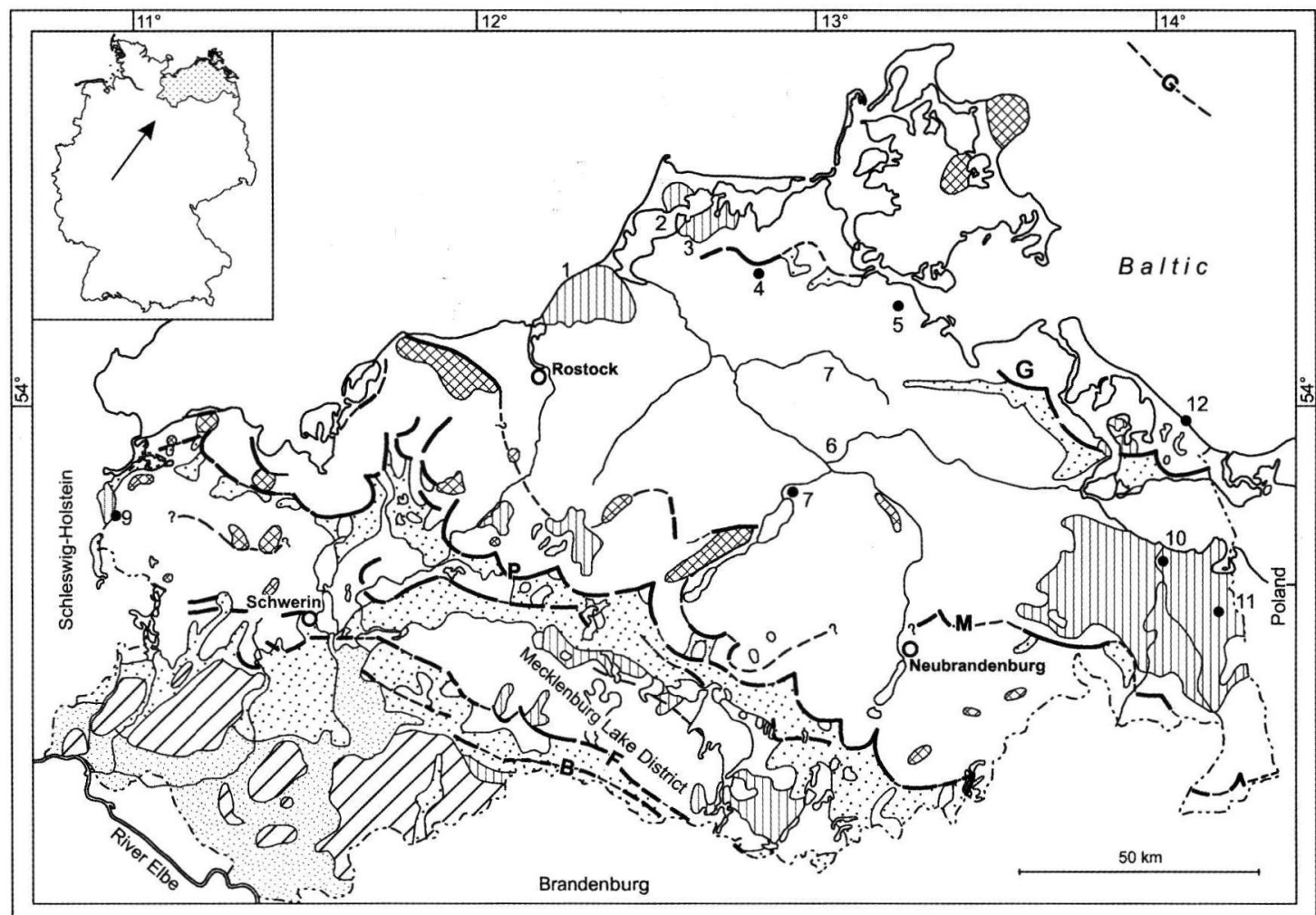

\section{Discussed sites and areas:}

1 Rostocker Heide area

2 Altdarss area

3 Barther Heide area

4 Endinger Bruch area with Final Palaeolithic sites Endingen VI and Nienhagen as well the pollendiagram HBG

5 Kettle hole Reinberg

6 "Valley grid" of Vorpommern

7 Till plains of Vorpommern

8 Late Palaeolithic sites at the river Peene bank near Verchen

9 Final Palaeolithic site Lüdersdorf

10 Profile Ueckermünder Heide (ZG 8 )

11 Late Palaeolithic sites Hintersee 24 and Mützelburg Forst 9 (MF 9)

12 Site Bansin
Glacial sediments and structures:

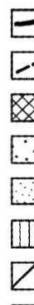

Push moraine

$\therefore$ Outwash plain

Ice-marginal valley

Targe glaciolacustrine basin

Saalian morainic deposits
Terminal moraines of the Weichselian:

B Brandenburg-stage ( $20 \mathrm{Ka} \mathrm{BP})$

F Frankfurt-stage

P Pomeranian-stage ( $15 \mathrm{Ka} \mathrm{BP})$

M Mecklenburg-stage

G Gardno-stage $(\sim 14 \mathrm{Ka} \mathrm{BP})$

Mainly till plain;

near the coast: coastal sediments

Fig. 1: Landscape structures in Mecklenburg-Vorpommern and the location of the study areas discussed in the text.

provide a basis for geomorphological and pedological research of hitherto unknown extent. New was the application of soil micromorphology, whereas detailed palynological analyses provided high-resolution pollen diagrams now covering the complete Lateglacial.

This paper summarises the current state of knowledge, compares some aspects with neighbouring areas, and integrates the results in a model of landscape development of Mecklenburg-Vorpommern during the Weichselian Lateglacial. It is in this sense the successor of two earlier summarising papers (BILLWITZ et al., 1998, 2000).

Interpretation of data of the Weichselian Lateglacial is complicated due to a widespread confusion on stratigraphic terminology (cf. e.g. BoKelmann et al. 1983; Bоск et al., 1985; Us- 
Tab. 1: Correlation of the vegetation phases of Vorpommern (cf. Fig. 5) with frequently used stratigraphic schemes of the Weichselian Lateglacial (after: De Klerk, 2002, p. 297). Dates in radiocarbon years BP.

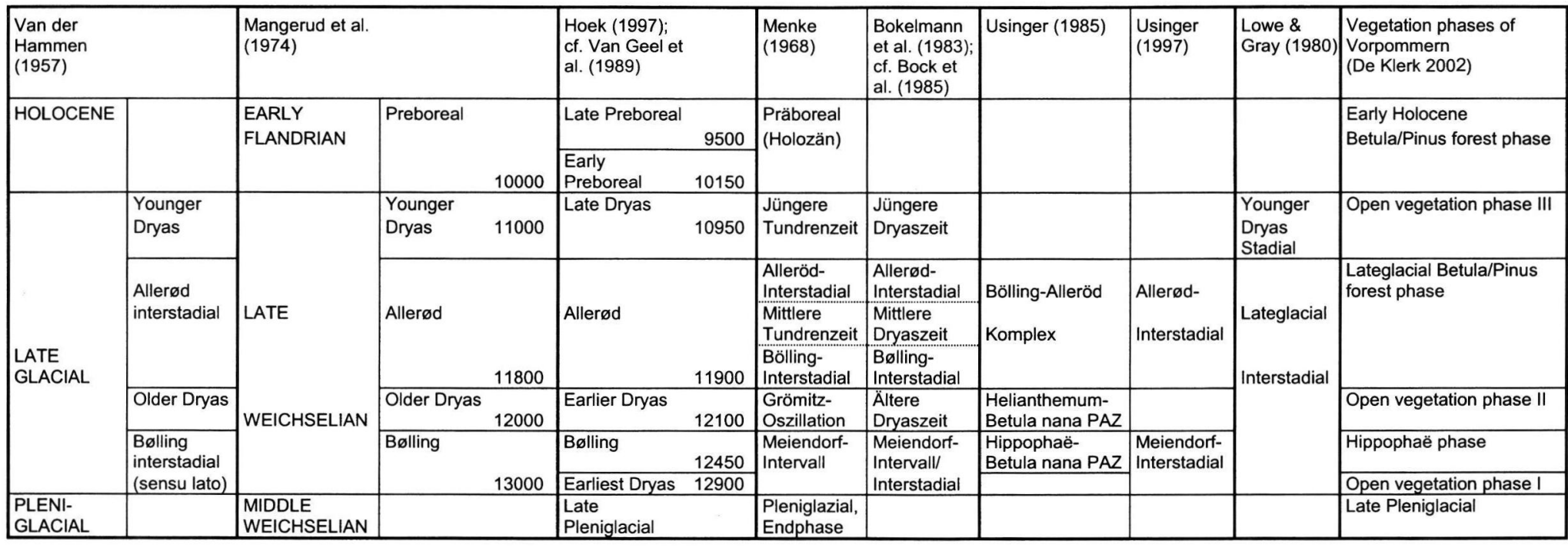


INGER 1985, 1997; LitT \& STEBICH 1999; LitT et al. 2001; De KLeRK 2002, 2004 b; ERIKSEN 2002) (cf. Table 1 and the section "vegetation history and palaeoclimate"). The present paper is neither suitable for a lengthy discussion on the terminological problems nor appropriate for the proposal of a solution out of the confusion. In this text, therefore, the 'traditional' terminology is used in a loose informal sense. The term "Bølling" is used according to the 'Dutch' stratigraphy of HoEK (1997; cf. VAN GEEL et al. 1989) and thus can be correlated with the later part of the "Meiendorf" (cf. Table 1). In many cases both terms can be combined as "Bølling/ Meiendorf". The term "Allerød" is used in its 'classical' sense and thus encompasses both the "Bölling-Alleröd Komplex" of Usinger (1985) and the sequence of "Bølling Interstadial - Mittlere Dryaszeit - Allerød Interstadial" or "Bølling - Oldest Dryas - Allerød" of Bokelmann et al. (1983), Bock et al. (1985) and Litt \& SteBich (1999) (cf. Table 1). The terms "Earliest Dryas" and "Earlier Dryas" are used according to the 'Dutch' stratigraphy of HoEK (1997) and VAN GEEL et al. (1989) (though the present authors do not completely agree on the dates of these phases as given in Table 1). The "Earliest Dryas" in this sense corresponds with the first part of the "Meiendorf" (cf. Table 1). Finally the concept of "Younger Dryas" (though "Late Dryas" would be more appropriate) is used in its 'traditional' sense (cf. IsARIN 1997 and Table 1).

Other scientific methods used in the various disciplines discussed in this paper were described in great detail in previous publications (e.g. Helbig 1999a; Kaiser 2001; De Klerk 2002; KüHN 2003a).
2 Sedimentation processes, geomorphological development and soil formation

\subsection{Deglaciation and development of basins and river valleys}

Three main Weichselian till beds and four major Weichselian terminal moraines are present in Mecklenburg-Vorpommern (MülLER et al. 1995; Fig. 1). Unfortunately, a reliable absolute chronology of the Weichselian ice decay is still absent. The extensive deglaciation after the Mecklenburg Glacial Advance dates around $14000{ }^{14} \mathrm{C}$ years BP according to radiocarbon data from the southern Baltic area (GöRSDORF \& KaISER 2001).

In recent years basins of all sizes as well as small valleys in Mecklenburg-Vorpommern were geomorphologically and palaeoecologically investigated. Together with material from older studies there are now around 100 informative and mainly palynologically dated lacustrine/fluvial sequences available for stratigraphic statements (KaIser 2002, 2004). The recent investigations, in contrast to the older studies, are characterised by a higher number of analysed profiles per basin („transect studies”) and a higher resolution of individual profiles.

The investigated basins can be classified as large glaciolacustrine basins (former proglacial lakes, $\left.>100 \mathrm{~km}^{2}\right)$, medium-sized lakes (0.03$\left.100 \mathrm{~km}^{2}\right)$, and kettle holes $\left(<0.03 \mathrm{~km}^{2}\right)$. The development of the Lateglacial large lakes in the southern Baltic basin (e.g. LEMKE 1998) will not be discussed here.

During the last deglaciation around $14000{ }^{14} \mathrm{C}$ years BP large proglacial lakes existed in the coastal region of NE Germany (cf. Fig. 1) in which at first layers of clay and silt sedimentated with thicknesses up to $5 \mathrm{~m}$, followed by a deposition of fine- and medium-grained sand up to $15 \mathrm{~m}$ thickness (Fig. 2A). Locally shallowwater gyttja and aeolian sand occur that date in the early Lateglacial, indicating that the final 
(4) Preboreal

\section{A Large glaciolacustrine basin (Altdarss-Barther Heide)}

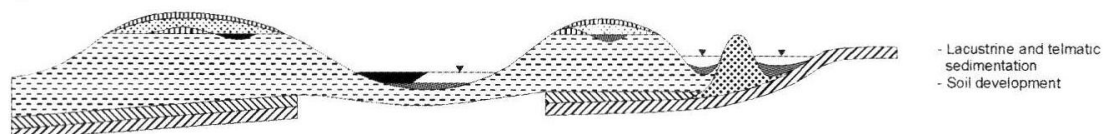

(3) Younger Dryas

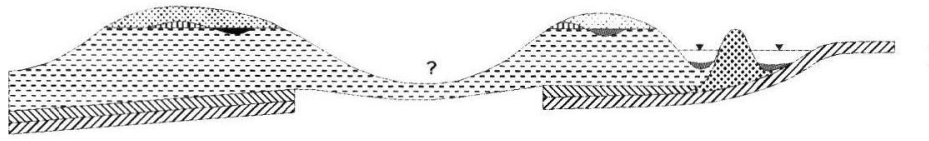

Aeolian processes sedimentation

(2) Allerød

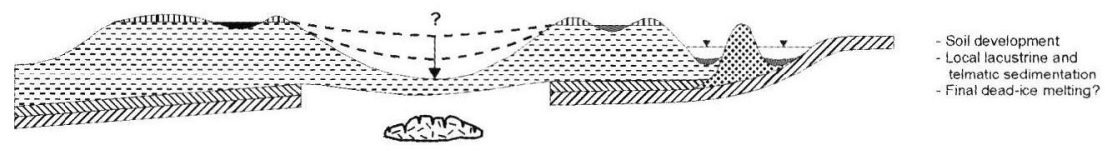

(1) Pleniglacial

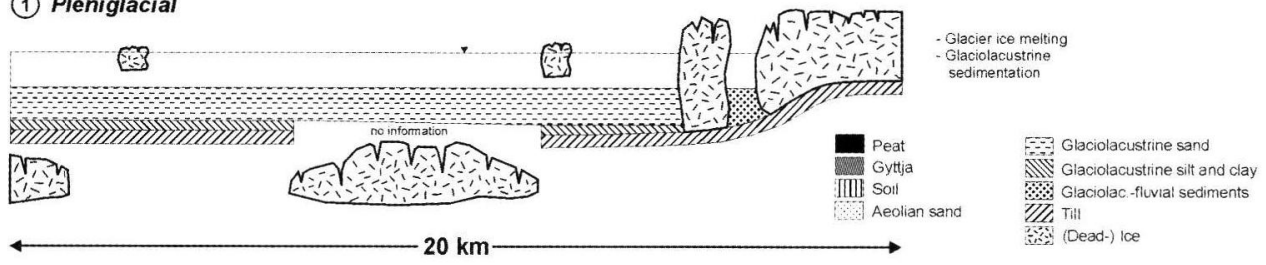

B Medium-sized lake basin (Endinger Bruch)

(5) Preboreal

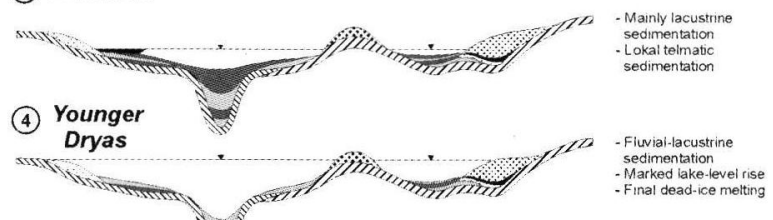

(3) Allerød

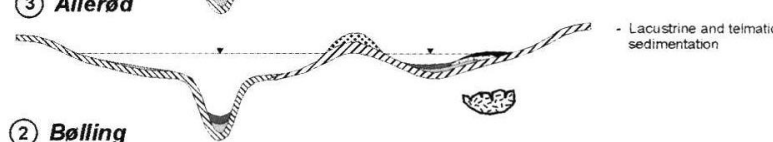

(2) Bølling

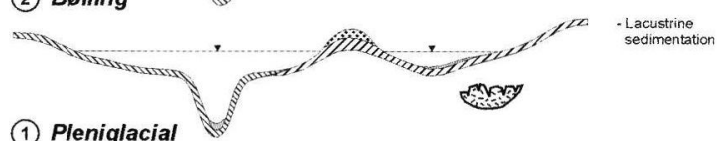

(1) Pleniglacial
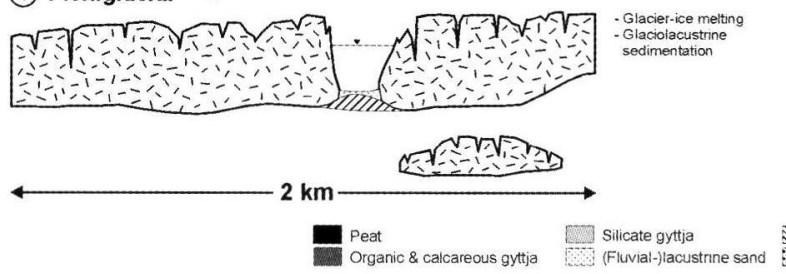

\section{Kettle hole (Reinberg)}

(5)

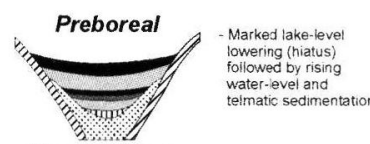

(4)

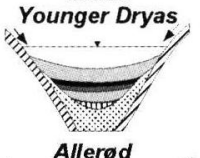

- Final teimatic

sedimentation
Erosion and lacustrine sedimentation
- Marked lake-level rise

(3)

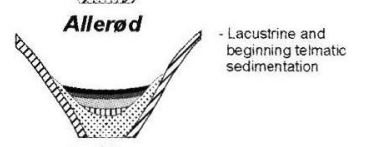

(2)

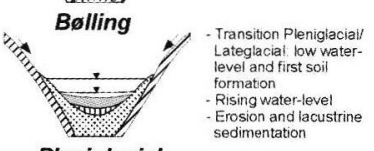

(1)

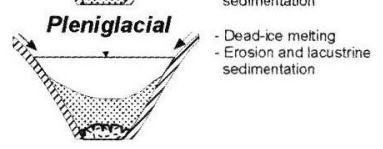

$\longleftarrow 0,2 \mathrm{~km} \longrightarrow$

NIV Glaciolacustnne sediments ZUA TIII IIIII Soil

Fig. 2: Late Pleistocene and Early Holocene basin development in NE Germany. A: Large glaciolacustrine basin, example Altdarss-Barther Heide (after: KaISER 2001); B: Medium-sized lake basin, example Endinger Bruch (after: KaISER 2001); C: Kettle-hole, example Reinberg (after: De KLerK et al. 2001). 
phases of large lakes occurred in the Pleniglacial (KaIser 2001). Particular varied and welldated findings from the late Lateglacial and early Holocene were derived from the basins of the Ueckermünder Heide (the area of the so-called "Haffstausee"), the Altdarss, and the Barther Heide area (e.g. KaISER 2001; Bogen et al. 2003; KüHN 2003a; KaISER et al. 2003, submitted). These findings include soils, peat beds and shallow-water gyttja which indicate that during the Allerød and the early Younger Dryas more or less dry conditions persisted in the large glaciolacustrine basins; lakes were only locally present (often as the result of dead-ice melting). During the late Younger Dryas basin sands were redeposited by wind over large areas. In the early Holocene these large basins were terrestrial - though locally also lacustrinetelmatic - in character. In the Atlantic period parts of the glaciolacustrine basins came under marine influence and became integrated in the Baltic Sea or in coastal lagoons.

The development of medium-sized lake basins within the time-frame under consideration can be illustrated with the Endinger Bruch area (approx. $12 \mathrm{~km}^{2}$ ) within the nearly flat till-plains in northern Vorpommern (Figs. 1, 2B). This area is with over 1000 geological profiles and a large quantity of chronological data one of the most intensively studied basins of this size in NE Germany (Terberger 1998; De Klerk 2002; KaISER 2004 b). Another intensively studied area is the Biesenthal basin $20 \mathrm{~km}$ north of Berlin (Снвовок \& Nitz 1995). An accelerated melting of buried dead-ice was reconstructed for the early Lateglacial (Earliest Dryas and Bølling). The majority of profiles show a beginning of sedimentation processes with silicate gyttja and organic silicate gyttja in the Bølling. The Earlier Dryas is characterised by deposition of predominantly clastic gyttja and fluvial sand that indicate a local sedimentary differentiation. The sediments of the Allerød (organic gyttja, calcareous gyttja, and peat) allow the reconstruction of a lacustrine environment without any fluvial influence. The final melting of dead-ice can be dated in the late Allerød or the early Younger Dryas. Fluviolacustrine sand (partly appearing as coarse sand bearing stones and blocks) was deposited during the Younger Dryas and indicate a maximal hydrological event involving a rise of the lake level of $2 \mathrm{~m}$ compared to the lake level of the Allerød. In the Preboreal a lowering of the water-level occurred with a "calm" lacustrine sedimentation.

The Lateglacial genesis of a kettle hole is shown with the Reinberg basin as example (DE KLERK et al. 2001; Figs. 1, 2C). Combined sedimentological, palaeoecological, and micromorphological investigations allow a high resolution study of the basin sequence. It was possible for the first time in the area glaciated during the Weichselian to give a characterisation of local palaeoenvironmental conditions within the basin of the transition from Pleniglacial to Lateglacial. The basal basin filling consists of (glacio-) lacustrine sands from the Pleniglacial in which a thin humous soil horizon (the "Reinberg horizon") has developed. During the early Lateglacial silicate gyttja was deposited, indicating a water body in the basin and a high water-borne input of suspended minerogenic matter from the surrounding basin slopes. In the Allerød mainly organic gyttja was deposited, indicating an increased primary production and reduced soil erosion. Formation of brownmoss peat started at the end of the Allerød and still continued at the onset of the Younger Dryas. Soon, however, a rise of the water-level induced the formation of a new water body with the sedimentation of a sequence of organic gyttja and silicate gyttja. In general the gyttja suggests an intensification of erosion processes attaining a maximum at the end of the Younger Dryas. A sudden lowering of water levels at the beginning of the Holocene is responsible for a sedimentary hiatus, which is a widespread phenomenon in small basins in NE Germany (cf. De KLERK 
2004 a). Afterwards a new water body did not develop in the Reinberg basin: only slowly rising water levels induced the development of a small peatland in which sedge/brownmoss peat was formed.

The sedimentation processes of medium-sized lakes and kettle holes in NE Germany are summarised by KaISER (2001). About $90 \%$ of these basins had a beginning of sedimentation in the Lateglacial, $38 \%$ in the Allerød. In general basin-forming dead-ice melting processes can be dated from the Pleniglacial up to the Early Holocene. An earlier phase of intensified deadice melting can be placed in the Earliest Dryas and Bølling/Meiendorf and a main concentration in the late Allerød and the early Younger Dryas. Over a third of the profiles include basal peat mainly from the Allerød, which ended regularly in a secondary position due to settling as the result of dead-ice melting. Characteristic for the Lateglacial is deposition of silicate gyttja, with the exception of peat and of gyttja deposits rich in carbonates and organic matter (mainly originating from the Allerød). The dominant silicate input during the Lateglacial is due to an only thin vegetation cover, disorder in the fluvial regime (braiding), and an unstable overall relief (abluation, gully erosion, dead-ice melting). Sedimentation of organic gyttja, calcareous gyttja and peat characterises the early Holocene. This is mainly due to a reduction of silicate input and an increase in primary production. Many basins show a prominent increase in lake-levels during the Younger Dryas (cf. e.g. KaISER 1996, 2001, in press b; Helbig 1999a; LORENZ 2003).

The fluvial structures in Mecklenburg-Vorpommern can be divided into a grid of large NE-SW- and NW-SE-oriented valleys in the east (i.e. following the direction of the glaciers, or following a direction along the glacier front) and into a 'chaotic network of small valleys' in the Mecklenburg Lake District in the west and south (cf. Fig. 1). Situated along the eastern and the western border of Mecklenburg-Vorpommern are the major Oder and Elbe river valleys which are not discussed in this paper.

Some older studies on formation and Lateglacial development of the eastern "valley grid" - summarised by JANKE (2002) - assume that valley incision is linked to the last deglaciation. Periodically the valley system drained the large proglacial lake of the "Haffstausee". The Lateglacial and Early Holocene are generally characterised by water-level fluctuations and phases of erosion and accumulation. For the Allerød relative low water-levels with sedimentation of organic gyttja and formation of peat were reconstructed, whereas the Younger Dryas seemed to be characterised by more intensive fluvial dynamics, higher water-levels and the sedimentation of clastic sediments. A phase of strong valley incision was identified for the end of the Younger Dryas and the Preboreal. In the early Holocene the valleys still contained small lakes formed by the melting of dead-ice. The groundwater-level was low in the flood plain area and terrestrial soils were formed.

Recently it was possible to investigate several smaller valleys of the "valley grid" of Vorpommern (Kaiser \& Janke 1998; Helbig \& De KLERK 2002). Valley sections show peat layers that could be dated to the Allerød covered by clastic sediments attributable to the Younger Dryas. This latter phase differs from the Allerød by seasonally larger discharges and prominent higher drainage levels in combination with more intensive fluvial dynamics. Incidentally lacustrine sediments were deposited during the early Younger Dryas. Compared to recent conditions, the channels with flowing water were much wider and drainage levels were 1$1.5 \mathrm{~m}$ higher during the Younger Dryas. Also the "chaotic network of small valleys" in the Mecklenburg Lake District shows evidence of intensified fluvial dynamics during the Younger Dryas (Rother 2003). There are indications that at the transition to the Holocene a braided- 
like fluvial pattern in the small valleys changed to a more stable single-channel system (Helbig \& De Klerk 2002; De Klerk 2004 a).

\subsection{Relic cryogenic macrofeatures}

\subsubsection{Sand-filled fissures and sand wedges}

In total about 80 sand-filled features were observed exclusively in the till plains of the Mecklenburg Glacial Advance. The frost structures reach only rarely depths of more than 180 $\mathrm{cm}$. Their shapes and widths are variable, but normally they have a width of approximately $10 \mathrm{~cm}$ in their central parts. The widths decrease at greater depths. Above the real fissure, a funnel-like upper opening occurs. All forms are without any exception filled with fine sand. Often they are covered by a layer of silty coversand ("'Geschiebedecksand") (Fig. 3): this is the upper part of the till that was influenced by former periglacial processes and by Lateglacial and Holocene pedogenesis (Helbig 1999a, 1999b; KüHN 2003a, 2003b).

The grain size distribution of the fissure fillings as well as quartz grain surface analyses clearly demonstrate that the filling material neither is eroded till material nor silty coversand, but that it is of aeolian origin. The filling sand shows often features of lessivation (i.e. brownish, vertical transferred clay is visible). The upper part of the sand structures is often disturbed. This is probably the result of solimixtion and of disturbance of the active layer by former permafrost or deep seasonally frozen ground (cf. KOZARsKi 1974; Hoffmann \& Blume 1977; Mackay 1993). Thickness of the disturbed zone and/or the silty coversand (including tilled soil) ranges between $30-70 \mathrm{~cm}$; mean thickness is $50 \mathrm{~cm}$. Many sand structures are more or less deformed. MuRTon \& French (1993) describe a downslope bending as a phenomenon of thawing sand-wedge sand that moved in downslope direction with the overlying material.
At the moment it is not possible to say whether the forms in Vorpommern are sand wedges or seasonally frozen ground soil wedges. Large, well developed sand wedges are known to indicate permafrost conditions (MURTON 1996). Smaller sand-filled wedges, on the other hand, also may occur outside the range of permafrost (Dijkmans 1989; Murton 1996; Murton et al. 2000). Direct dating of the filling sands by means of radiocarbon dating or thermoluminescence was not succesful (Helbig 1999a). Considering the present knowledge on the Lateglacial palaeoenvironment of Vorpommern the most favourable conditions of formation were during the period between the deglaciation and the beginning of the Lateglacial and during the Younger Dryas. Because most of the features in Vorpommern are not large and well developed, there are three possibilities for their genesis:

1: Formation might have been under conditions of continuous permafrost during the late Pleniglacial. In that case large forms could not develop because too little time remained until temperatures rose at the beginning of the Lateglacial.

2: Formation was under conditions of discontinuous permafrost during the late Pleniglacial and early Lateglacial or Younger Dryas. In that case the higher temperatures (compared to continuous permafrost conditions) as well as the too short time-span limited the growth.

3: The structures were formed under conditions of strong seasonally frozen grounds during the late Pleniglacial and/or early Lateglacial or the Younger Dryas: then large forms could not develop because temperatures were too high.

A main or second phase of sand wedge development during the Younger Dryas cannot be excluded (KüHN 2003b). A prerequisite for the formation of primary mineral-filled frost wedges is aeolian sand transport on a snowfree surface in winter (Dijkmans 1989): this indicates cold and dry climatic conditions in 


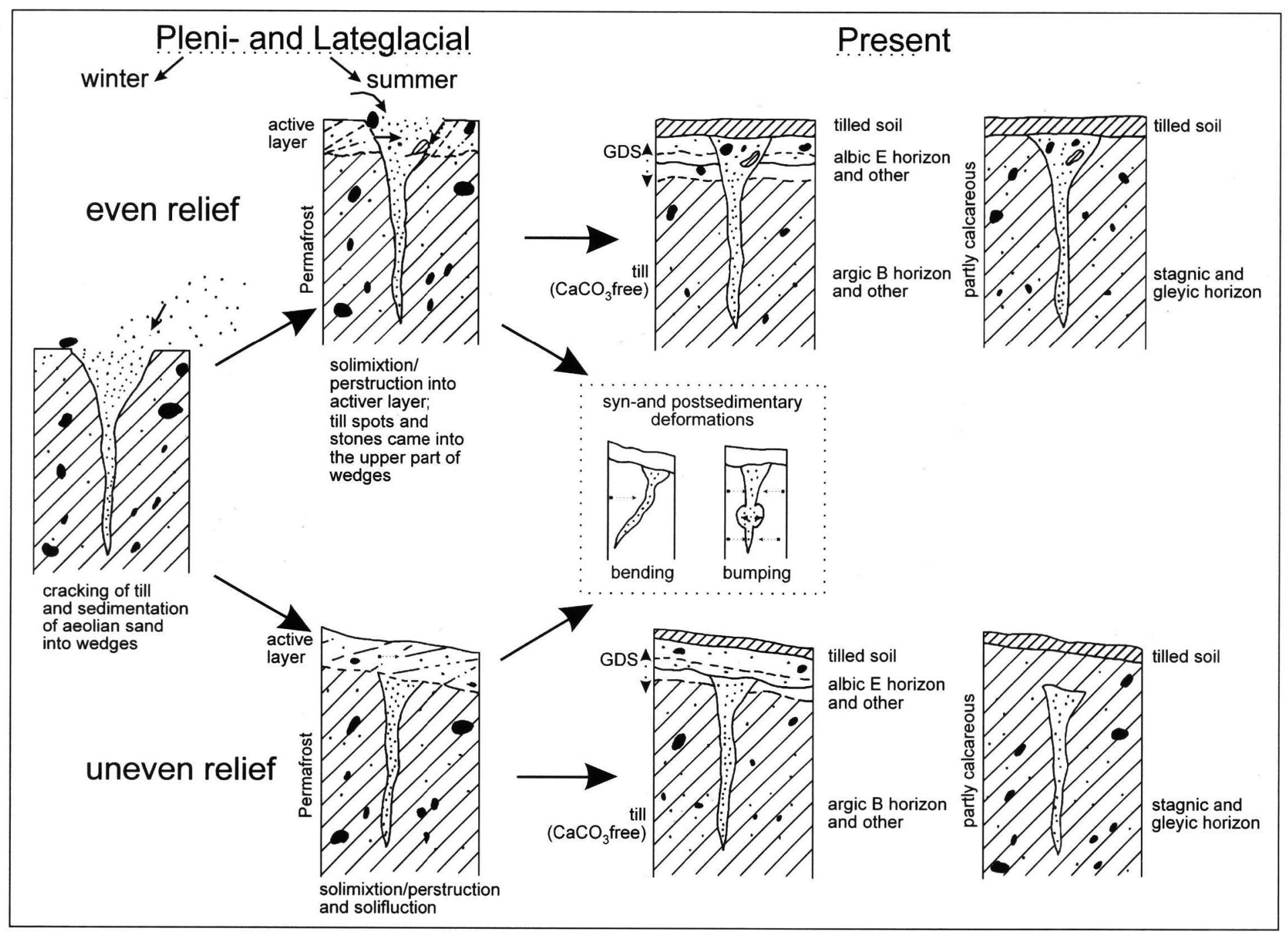

Fig 3: Genesis of relic sand fissures under influence of the active layer and of pedogenetic processes. 
Vorpommern during the formation of the fissures. However, sand-wedge formation might have occurred at wind-exposed and snow-free sites, which therefore might only indicate dry microclimatic conditions.

\subsubsection{Cryoturbations}

Most cryoturbations are located in sediments of basins and valleys because of their high amount of soil water and a layering of sediments of different texture (Helbig 1999a). Typical are both diapirs and drop-like forms. On higher till plains deformations in sand-filled fissures occur. The fissures show bump-like deformations due to thaw and freeze cycles.

In two cases cryoturbations could be positively dated in the Younger Dryas: at the locations „Bansin” (Helbig 1999a) and „Grimmen 4" (Helbig \& De Klerk 2002). At some other localities cryoturbations occur in sand that also is likely to date from the Younger Dryas (HeLbig \& De KLerk 2002).

The cryoturbations described in this paper and by Kliewe \& Schultz (1970) belong to the smaller forms (amplitude $<0.6 \mathrm{~m}$ ) sensu VANDENBERGHe (1988), who states that these are an indication for a Mean Annual Air Temperature (MAAT) $\leq-1^{\circ} \mathrm{C}$. With the due caution because of the only few hard datings, this value may count as indication for the temperature regime in Vorpommern during the Younger Dryas.

\subsection{Aeolian processes}

Aeolian sand sheets and sand dune complexes in Mecklenburg-Vorpommern cover a total area of approximately $450 \mathrm{~km}^{2}$ (SEELER 1962). Dune fields mainly occur in the SW part of the Federal State (extension ca. $300 \mathrm{~km}^{2}$ ) on the Weichselian outwash plains and on the adja- cent Saalian till plains. Other areas with Lateglacial aeolian sediments are within the large glaciolacustrine basins in the coastal region of today's Baltic Sea and in the distal parts of the large outwash plains of the Mecklenburg Lake District (cf. Fig. 1). After an initial formation during the Late Pleistocene/Early Holocene, the aeolian landscapes were strong influenced by man-made erosion and accumulation during the Late Holocene (Kaiser et al. 2002).

An exceptional feature in the Weichselian till plains of Vorpommern is the occurrence of some loess deposits; there are, however, no detailed sedimentological analyses of these sediments (cf. Schönhals 1944; Bramer 1961). A study from NW Poland demonstrates that on a local scale sedimentation of loess might have occurred in the late Pleniglacial north of the Pomeranian terminal moraines (IsSMer 1999). The accumulation of silt in ca. $30 \%$ of the topsoil-profiles (silty coversand: see above) indicates that some aeolian activity also occurred on a broader scale. Similar finds can be found in buried soils and lacustrine sediments. Ice wedges filled with fine sands indicate aeolian activity during the Pleniglacial and early Lateglacial or Younger Dryas on the till plains.

During recent years dunes and sand sheets were identified in the large glaciolacustrine basins of the Ueckermünder Heide, the Rostocker Heide, the Barther Heide and the Altdarss area that could be attributed to the Younger Dryas with various dating methods (KaISER 2001; KüHn 2003a; Ludwig 2002; Bogen et al. 2003; KaIser et al. submitted; cf. Fig. 4). Furthermore there are indications of some local aeolian activities during the Older Dryas. As a rule, the aeolian sands of the Younger Dryas cover terrestrial soils („Finow-Soil”, “UsseloSoil"), peat, or gyttja. The various dates allow the assumption that stable land surfaces still persisted in the early Younger Dryas: the aeolian processes therefore, must be placed in the later Younger Dryas and the Younger Dryas-Prebo- 


\section{Rostocker Heide} (Cliff)

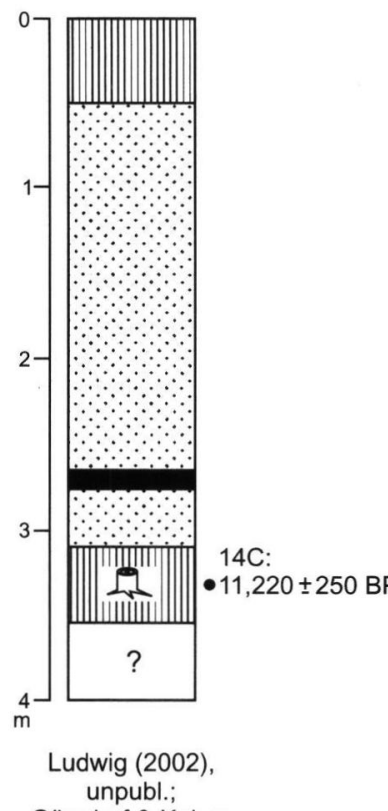

unpubl.;

(2001)

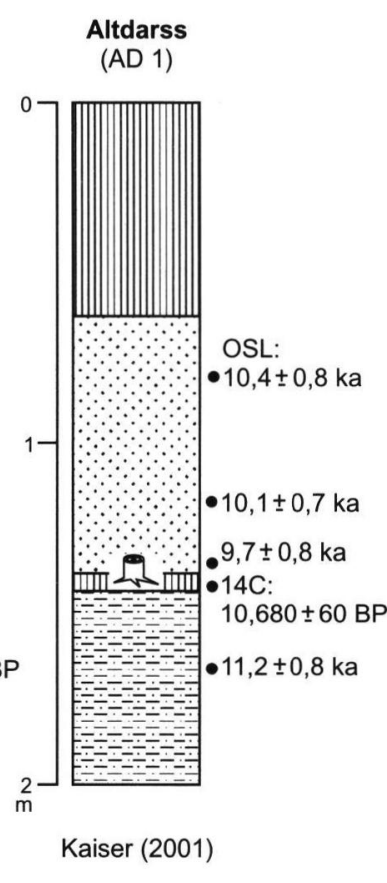

Lithology:

血向
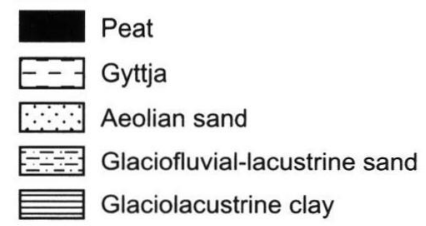

If Tree-stump (pine)
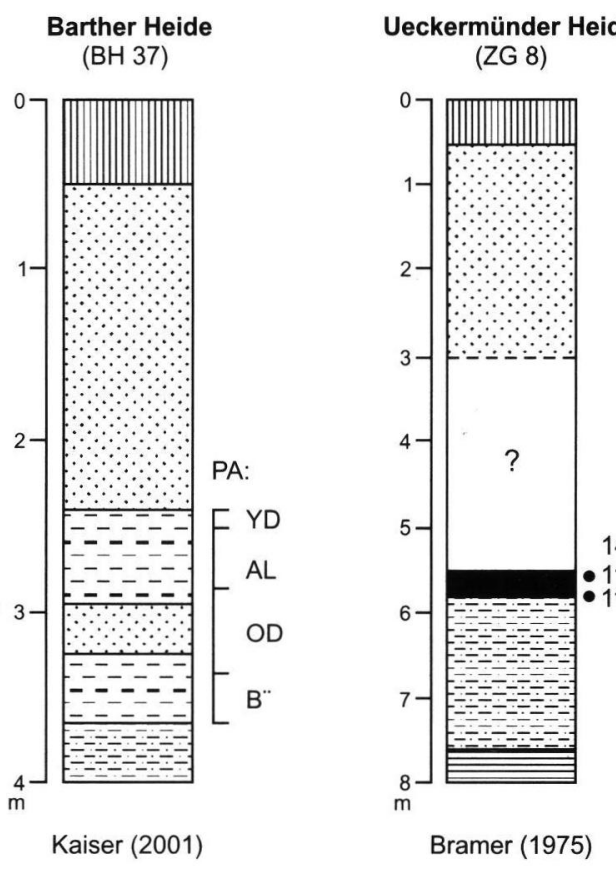

Dating:

14C Radiocarbon date

OSL OSL date

PA Pollen analysis:

$$
\begin{aligned}
\mathrm{YD} & =\text { Younger Dryas } \\
\mathrm{AL} & =\text { Allerød } \\
\mathrm{OD} & =\text { Earlier Dryas } \\
\mathrm{B}^{\prime \prime} & =\text { Bølling }
\end{aligned}
$$

Ueckermünder Heide

(MF 9)

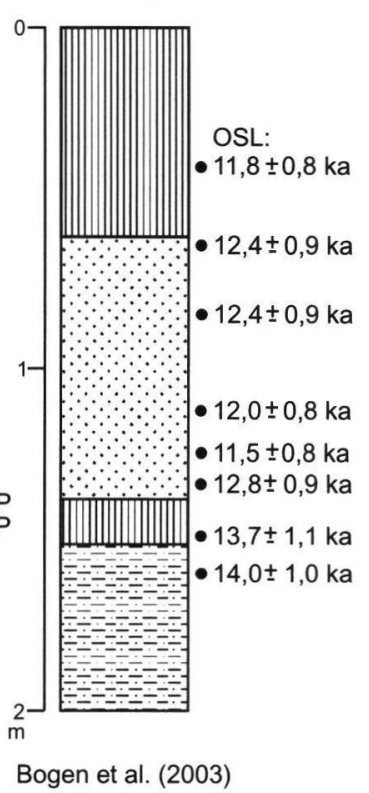

Fig. 4: Dated dunes and cover sand profiles in Northeast Germany. 
real transition, respectively (KAISER in press a). The lithological features allow the reconstruction of aeolian episodes/events. The aeolian sediments can be parallelised with the "younger cover sands" as found in NW Germany, NW Denmark and in The Netherlands (Kolstrup 1991; Kasse 1999). Until now there is no evidence found in Mecklenburg-Vorpommern of aeolian activity during the early Holocene as is known from Brandenburg and W Poland (Bussemer et al. 1998; Schirmer 1999) with the exception of the Elbe river valley (CASPERS \& SCHWARZ 1998).

A prominent morphological differentiation of aeolian formations is observable: in the northwestern and southern regions of Mecklenburg-Vorpommern there is a dominance of aeolian sand covers up to $4 \mathrm{~m}$ in thickness with weakly developed relief and low dunes, whereas some prominent dune complexes of up to about $25 \mathrm{~m}$ in height exist in the southwestern and the eastern regions. It is uncertain whether this reflects a palaeoclimatic differentiation ("oceanic/ continental", cf. BösE 1991) or whether a more or less random cause should be assumed, i.e. dependent of the form and consistency of the aeolian drift areas. The position of aeolian sand sheets and dune fields in the medium-scaled relief, the orientation of dated longitudinal and parabolic dunes, and measurements of the direction of deposition suggest that sand was mainly transported from west to east during the Younger Dryas (KaISER 2001).

\subsection{Soil formation}

Research into Lateglacial soil-genetic processes was twofold: on the one hand studies concentrated on soils influenced by (ground)water, on the other hand relic and buried soils of terrestrial sites were investigated. The discovery of the "Reinberg horizon", a fossil Ah-horizon (DE KLERK et al. 2001), date the oldest known soil formation in NE Germany after the Weichselian glaciation at the transition from the Pleniglacial to the Lateglacial. New results on the Lateglacial formation of soils influenced by groundwater (e.g. Gleysols, Dystric Gleysols, Histosols, and peat horizons) were predominantly derived in the context of studies on landscape genesis (Kaiser 2001).

Several soil types could be demonstrated for terrestrial sites with sandy parent material, such as weakly podsolised Regosols, Arenosols and peat layers in the areas of the Rostocker Heide, Altdarss, and Barther Heide (KaISer 2001; KaISER et al. submitted), and thin Cambisols (Bwb-horizons) near Lake Krakower See (Lorenz 2003) and in the Ueckermünder Heide area (Bogen et al. 2003; KüHN 2001, 2003a). The thin buried Cambisols are comparable with the so-called Finow soil in Brandenburg (cf. (Bussemer et al. 1998). These Bwb-horizons are stratigraphically positioned similarly as the Usselo soil in The Netherlands and Poland (cf. Van Geel et al. 1989, MaNiKOWSKa 1991).

A ca. $3 \mathrm{~km}^{2}$ large Lateglacial surface buried by aeolian sands was discovered in the Altdarss area (KaIser submitted; cf. Fig. 4). Tree-stump horizons of Pinus as well as wood remains of Betula and Populus were excavated in-situ. These buried soils (Histosols, Gleysols, podzolic Arenosols) could be dated into the earlier part of the Younger Dryas by means of radiocarbon dates, OSL dates and palynological analysis. The covering with aeolian sand, thus, must have occurred during the Younger Dryas-Preboreal transition.

Polygenetic Lateglacial/Holocene soils are widespread on the gently undulating till plains (inclination mostly $\leq 2^{\circ}$ ) of the Mecklenburgian glacial advance. Dominating soil types are albi(c)(-stagnic) Luvisols and (stagnic) Albeluvisols sensu FAO (1998) with a simplified typical horizon sequence $\mathrm{Ap} / \mathrm{Bw} /(\mathrm{Eb}) /(\mathrm{EBtb}) /$ $\mathrm{Btb}(\mathrm{g}) / \mathrm{C}$ (KüHn 2003a, 2003b). Basal boulder clay (sandy loam to loamy sand), which is the 
parent material of soil formation, is largely covered by a silty sand-layer of $40-70 \mathrm{~cm}$ in thickness. Cambic horizons were formed mainly in this silty sand-layer, whereas the (stagnic) Luvisols predominantly occur in the boulder clay (Helbig 1999a; KüHn 2003a).

It is still widely accepted that periglacial solimixtive processes during the Late Weichselian caused homogenisation of the upper 40-70 $\mathrm{cm}$ of the ground, the silty coversand and led to the formation of the "Geschiebedecksand" (Bussemer 2002). Nevertheless the genesis of silty coversands in the North German lowlands is recently discussed to be mostly of Holocene pedogenic origin (HelBig 1999a). Up to now the Luvisols mentioned above were interpreted to have been formed during the Holocene (e.g. Reuter 1990) or during the Lateglacial (Kopp 1970).

Systematic micromorphogenetic investigations of (Albe-)Luvisols (KüHN 2003a, 2003b) revealed that numerous fragments of rounded limpid clay coatings occur within periglacial formed lenticular micro-plates. As the Younger Dryas is the latest phase during which these lenticular micro-plates can have been formed, the clay illuvation must have occurred earlier. Also fragments of clay coatings in periglacial formed Bt-streaks (occurring in $\mathrm{E}$ - and $\mathrm{E}+\mathrm{Bt}$-horizons) prove that clay illuvation occurred during the Lateglacial. Undisrupted clay coatings next to fragments of clay coatings in both cases mentioned previously show a subsequent clay illuvation during the Holocene (KüHN et al. 2002). These micromorpho-stratigraphic findings are supported by a buried Lateglacial Bt horizon in the Ueckermünder Heide area (KüHN 2003a: 59). The aeolian sediments, covering this Bt horizon were OSL-dated at $9.6 \pm 0.6 \mathrm{ka}$. A younger formation of the $\mathrm{Bt}$ horizon can be excluded by micromorphological analysis.

Contrary to the widely accepted soil-genetic hypothesis of a formation of Luvisols exclusively during the Holocene, therefore, clay illuviation is a pedogenic process that also occurred during the Lateglacial, at least during the warmer phases. Other pedological processes that already were accepted for the Lateglacial on sites not influenced by groundwater are decalcification, accumulation of organic matter (formation of Ahb-horizons), podzolisation, and silicate weathering (formation of Bwb-horizons).

\section{Vegetation history and palaeoclimate}

With the palynological study of the cores Reinberg C (De Klerk et al. 2001) and Hoher Birkengraben (De KLERK 2002, Fig. 5) high-resolution pollen diagrams from Vorpommern became available that cover the complete Lateglacial. In order to interpret and correlate pollen diagrams from NE Germany independent of the existing confusing on stratigraphic terminology a sequence of 'Vegetation phases of Vorpommern' was introduced (De KLERK 2002; cf. Table 1). These vegetations phases, however, are only applicable for palynological data and hardly have relevance for geomorphological, pedological or archaeological studies, as these are mainly carried out without direct connection to palynological investigations. A discussion of the vegetation history in terms of Greenland Stadial and Interstadials as proposed by the INQUA-INTIMATE Group according to the oxygen isotope record in the Greenland ice-cores (BJörcK et al. 1998) is still hazardous due to the absence of a combined palynological and oxygen isotope dataset in NE Germany. The newly proposed biostratigraphy of the Eifel region of LITT \& Stebich (1999) and Litt et al. (2001), that predominantly follows the stratigraphic views of B. Menke (Menke 1968; Bokelmann et al. 1983; Bock et al. 1985; cf. Table 1), is based on a stratigraphic/geochronologic scheme that is illogically defined, and uses a revised interpretation of the type locality Bøllingsø that is insufficiently supported by the actual dataset of 


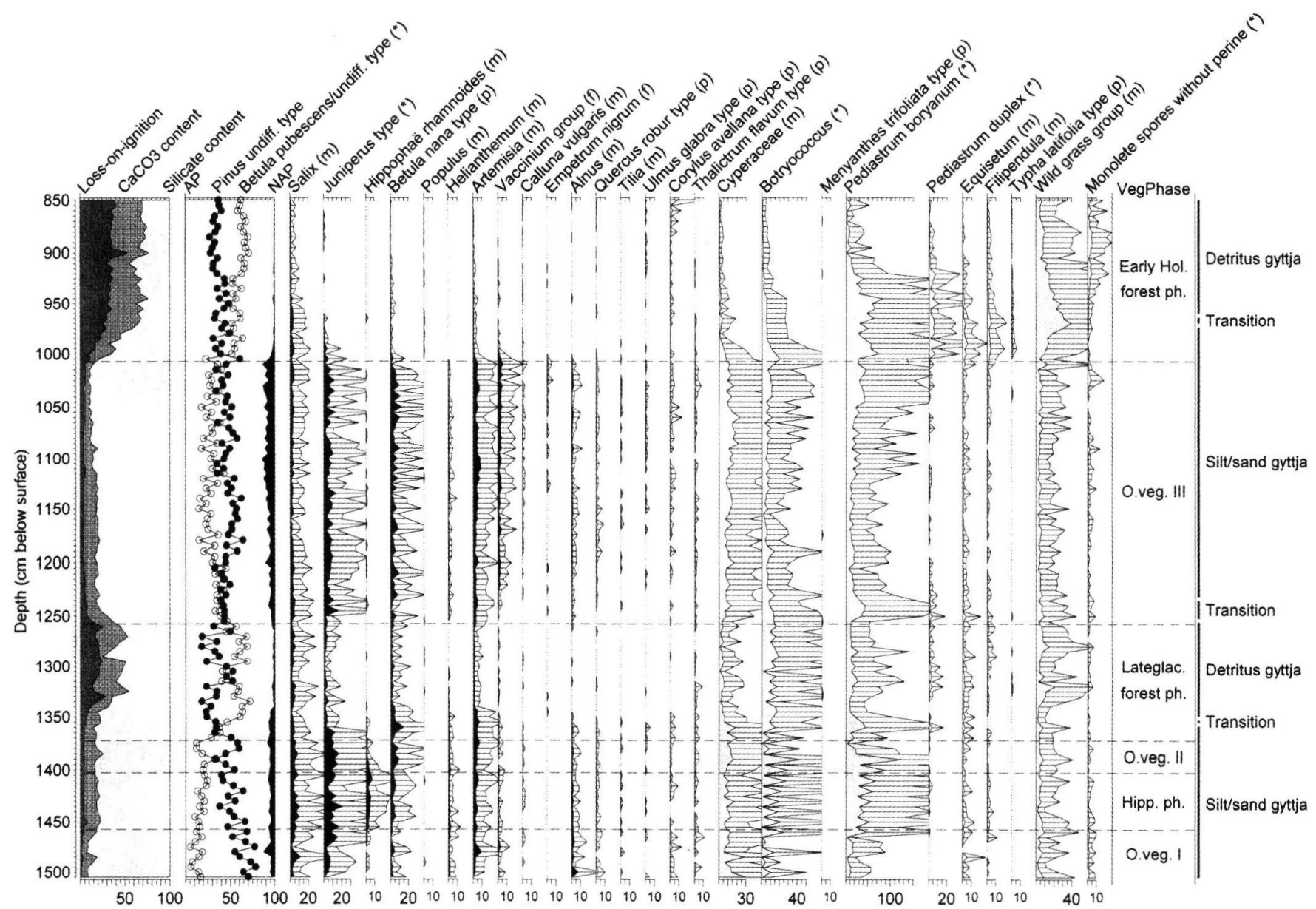

Fig. 5: Pollen diagram 'Hoher Birkengraben' from the Endinger Bruch, selected pollen types (modified after De KLERK 2002). The curves are displayed with an additional 5-times exaggeration (open curves with depth bars). Solid curves: types included in pollen sum; dotted curves: types excluded from pollen sum (for pollen frequency calculation and pollen type nomenclature see DE KLERK 2002). For details on pollen type nomenclature (f, $\mathrm{m}$, p, ${ }^{*}$ ) see De KLERK (2002). 
this locality (cf. De KLERK 2004 b). For these reasons, the present authors are the opinion that the LitT \& Stebich (1999) and LitT et al. (2001) stratigraphic/geochronologic scheme is a somewhat problematic alternative to the traditional division of the Weichselian Lateglacial. Since hardly any reliable (AMS-) ${ }^{14} \mathrm{C}$-dates are connected directly with pollen diagrams in Mecklenburg-Vorpommern, a chronology of the vegetation phases as presented by DE KLERK (2002) is still a matter of hypothetical correlation and interpretation.

During the first vegetation phase in the Lateglacial, the Open vegetation phase I (Earliest Dryas or earlier phase of the Meiendorf; cf. Fig. 5), the upland was inhabited by a vegetation of predominantly herbs and (dwarf)shrubs. Incidentally, also Betula trees must have been present, as could be demonstrated in the Reinberg researches (De Klerk et al. 2001). This phase starts probably with an only minor temperature rise compared to the preceding Pleniglacial (DE KLERK et al. 2001) and, thus, must be interpreted as still relatively cold compared to the following Lateglacial vegetation phases.

During the Hippophaë phase (Bølling/Meiendorf) Hippophaë thickets expanded prominently in this open landscape. As Hippophaë needs relative high summer temperatures for flowering (Kolstrup 1979), this phase is interpreted to have been relatively warm (De KLERK 2002; De KLerk et al. 2001). The fact that Hippophaë shrubs were not outshadowed by expanding Betula trees suggests that climate was too dry for the latter taxon to expand considerably (cf. UsINGER 1997), or that soil conditions were still immature (cf. VAN GeEl 1996).

Open vegetation phase II (Earlier Dryas) was again dominated by herbs and (dwarf)shrubs. Especially some minor diagrams from the Endinger Bruch area (DE Klerk 2002) indicate prominent stands of Juniperus. This indicates that this vegetation phase represents a vegetation regression, which is probably the result of a decrease in summer temperatures (DE KLERK 2002). A comparison of pollen diagrams from northern Vorpommern with those of S Mecklenburg, $\mathrm{N}$ Brandenburg and the Berlin area carried out by De Klerk (2002) and De KlerK \& Stolze (2002) shows that this vegetation phase is not or only very slight discernible in the southern pollen diagrams. This is interpreted to be the result of higher summer temperatures in the southern regions due to which Hippophaë was able to maintain itself for a longer period, or in these regions climate and/or environment was more favourable for Betula trees which consequently expanded earlier than in the northern regions and suppressed Hippophaë.

Sediment data from the Reinberg basin indicate that during the Lateglacial precipitation had gradually increased (De KLeRK et al. 2001). As a result of this, and/or as the result of the development of more mature soil conditions, Betula trees were able to expand in northern Vorpommern at the beginning of the Lateglacial Betula/ Pinus forest phase (Allerød). The upland vegetation, however, remained predominantly open for some time (cf. Fig. 5). A sharp decrease in NAP-values around $1340 \mathrm{~cm}$ depth marks the sudden closing of the birch forests: these now dominated the upland. The low values of pollen attributable to Pinus indicate an only minor presence of pine trees during the Lateglacial Betula/Pinus forest phase. This is in contrast with pollen diagrams from $S$ Mecklenburg, Brandenburg and the Berlin area, which show a prominent Pinus phase in the later period of the Allerød. This difference is attributed to a dominance of pine on the sandy soils of the prominent outwash-plains in the south, whereas the northern till plains carried a forest of predominantly birch trees (Theuerkauf 2003).

The sharp decrease in $\mathrm{CaCO}_{3}$-content in core Hoher Birkengraben around $1285 \mathrm{~cm}$ depth (cf. Fig. 5) might reflect a sedimentary reaction on a short-time acidification of the environment after the Laacher See eruption: the 'Re- 
inberg C' pollen diagram includes the Laacher See tephra at a palynostratigraphic level similar to the decline of $\mathrm{CaCO}_{3}$-content in Fig. 5. An analysis of many pollen diagrams from NE Germany indicates that the vegetation probably did not directly react on a decrease of temperatures induced by the volcanic eruption; increased precipitation and consequent temporal water level increases, as well as extremely intensive lightning activity and consequent increased fire might have temporarily disturbed the vegetation on a small scale (cf. Theuerkauf 2003; De KLERK et al. submitted).

The pollen diagram of Fig. 5 shows that during Open vegetation phase III (Younger Dryas) an open upland vegetation consisting of Artemisia, Ericales, several shrubs such as Juniperus, Hippophaë, dwarf birches, and probably shrubs of Salix, persisted. Trees of Betula and Pinus most likely were present as single specimens, not forming closed stands. NAP-values show that maximum openness occurred at the end of this phase. As far as openness is related to cold, this contradicts studies that place maximum coldness of the Younger Dryas at its beginning (cf. e.g. Isarin 1997; Isarin \& BohnCKe 1999). Openness, however, may also be the result of drought.

It is remarkable that in pollen diagrams from $\mathrm{N}$ Vorpommern the Younger Dryas is represented without any exception with thicker sediments than those of the Allerød, while in general (but not always) a change from organic sediments to clastic sediments occurs. In the southern regions, on the contrary, the sediments from the Allerød always are the thicker ones (as far as these are completely preserved), and a change to clastic sediments normally does not occur. It is interpreted that these differences are caused by a denser vegetation (at least along the basin slopes) in the southern regions due to which soil erosion was severely hampered and consequently thick clastic sediments were not washed into the basins. This denser vegetation also is attributed to slightly warmer conditions in the southern regions than in the north (cf. DE Klerk 2002; De Klerk \& Stolze 2002).

The sharp decrease of NAP-values at the transition to the Early Holocene Betula/Pinus forest phase (Preboreal; cf. Fig. 5) shows that the upland vegetation suddenly closed: dense forests of birch and pine trees developed rapidly. The vegetation probably reacted on the rise in temperature without major time-lag, as the forests could develop quickly from the incidental stands of birch and pine already present in the previous open phase (cf. Hoek 2001). At the beginning of the Early Holocene Betula/Pinus forest phase several Lateglacial 'relic' plants still must have been present, as can be concluded from the values of pollen attributable to Juniperus, Betula shrubs, Artemisia, and Ericales (cf. Fig. 5). Along the basin margins a lake-shore vegetation consisting of Typha latifolia, Equisetum, Filipendula and later Poaceae (possibly Phragmites) seem to have developed. A short, open vegetation phase during the Early Holocene as reconstructed for other regions in Europe (Behre 1978; Van Geel et al. 1981) is not registered in the diagram Hoher Birkengraben: the conspicuous peak of pollen attributable to wild grasses is interpreted as a pollen signal of the wetland vegetation and not as an expansion of upland grasses (cf. De KLERK 2002).

The observed differences between the northern and the southern regions indicate that during the Lateglacial a sharp climate gradient existed in NE Germany. A present gradient is explainable by the influence of the Baltic Sea, but it is more difficult to explain such phenomenon for a period where the Baltic Sea did not yet exist. Steep climate gradients in Europe during the Lateglacial, however, might be due to the existence of steep temperature gradients between the ice cover in Scandinavia and the prominent continental climate on the ice-free continent (cf. Coope \& Lemdahl 1995). 


\section{Development of the fauna}

As evidence on the Lateglacial and early Holocene faunal record of NE Germany is limited, it is necessary to integrate information from neighbouring areas as well. Recent studies demonstrated that earlier dates of important faunal finds based on stratigraphic or palynological observations alone are sometimes unreliable. An AMS-date of the aurochs skeleton from Potsdam-Schlaatz (Brandenburg), traditionally dated to the Younger Dryas, now ascribes the find to the early Preboreal (Benecke 2002). Although direct dating makes progress (cf. e.g. LiLjegren \& Eкström 1996), there is still unreliable information incorporated in the Lateglacial faunal record of N Germany and $S$ Scandinavia (Fig. 6).

The large mammal fauna of the early open vegetation phase (Bølling/Meiendorf) was probably dominated by reindeer (Rangifer tarandus). This is demonstrated by numerous reindeer remains form the well known Meiendorf site north of Hamburg (Krause 1937). Also in Denmark there is evidence of this species for that period since ca. $12500{ }^{14} \mathrm{C}$ years BP (AAris-Sørensen 1992; Holm 1996). In Scania reindeer is not present before $12000 \mathrm{BP}$ because there was probably previously no landbridge (continuously) established for the seasonal migrations of the species at that time.

At Meiendorf reindeer remains from the Bølling/Meiendorf are accompanied by few horse (Equus ferus) remains, whereas two elk (Alces alces) bones detected above the find layer cannot be reliabely ascribed to the Bølling/ Meiendorf (cf. KRAUSE 1937). An isolated AMS-date of elk remains from Scania suggests presence of the species in northern regions around ca. 12400 BP (Liljegren \& EkströM 1996). It is also possible that wolf (Canis lupus) already lived in the Danish territory at the end of the Bølling/Meiendorf (AARIs-Sørensen 1992, 146). Smaller faunal elements like hare, grouse, some birds and fish also contributed to the faunal record in Schleswig-Holstein (Krause 1937).

Remains of mammoth (Mammuthus primigenius) were not found at archaeological sites from the Bølling/Meiendorf in the north. The youngest mammoth finds from South Scandinavia are dated at ca. $13000{ }^{14} \mathrm{C}$ years $\mathrm{BP}$ and it is argued that the species closely followed the retreating ice front (AARIs-SøRENSEN 1992; LiLJEGREN \& Екsтröм 1996). Engraved stone slabs from Gönnersdorf demonstrate that the large herbivore was known in the Rhineland in the Magdalénien (Street et al. 1994; Terberger 2002), but mammoth was of no relevance for the subsistence strategy at that time. Although information is limited, reindeer seems to be the dominant (hunting) game of the early Lateglacial in the northern lowlands. It is unclear to what extent the exploitation of sea mammals was important at that time (cf. e.g. SerangelI 2003).

The faunal record in Vorpommern during the Allerød is demonstrated at the site Endingen VI where some elk bones prove hunting of the species. Elk is also represented at Klein-Nordende (Schleswig-Holstein) dated to ca. $12000{ }^{14} \mathrm{C}$ years BP (Bokelmann et al. 1983). Because elk is also present at sites in Denmark it can be assumed that this species was an important hunting game in the early Allerød (Fig. 6). A worked giant deer (Megaloceros giganteus) antler piece from Endingen VI and another isolated find of a worked skull of giant deer from Lüdersdorf suggest that this large herbivore also lived in the Allerød landscape of NE Germany. Some giant deer remains from Denmark and Scania demonstrate that this species also existed in these regions around $11600{ }^{14} \mathrm{C}$ years $\mathrm{BP}$ (cf. KAISER et al. 1999). The presence of a herbivore with a possible antler width of more than $3.5 \mathrm{~m}$ indicates that the forest cannot have been very dense and that open environments still must have existed in the Allerød. This interpretation is supported 


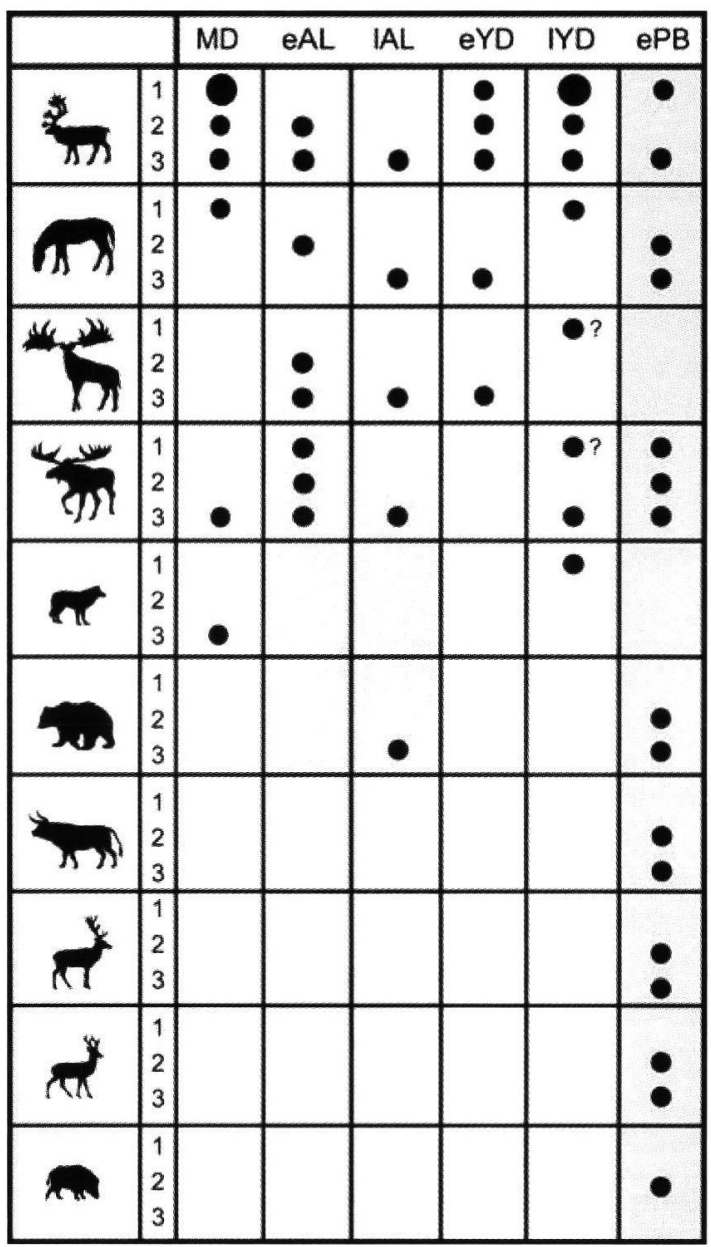

Fig. 6: Evidence of Lateglacial large mammals in Schleswig-Holstein (1), Mecklenburg-Vorpommern/ Brandenburg (2) and Denmark/Scania (3). MD: Bølling/Meiendorf; eAL: early Allerød; lAL: late Allerød; eYD: early Younger Dryas; IYD: late Younger Dryas; ePB: early Preboreal. Sources: Krause (1937), AarisSørensen (1992), Eriksen (1996), Liljegren \& Ekström (1996), Benecke (2000, 2004), Clausen (2004). Order of species: reindeer, wild horse, giant deer, elk, wolf, brown bear, aurochs, red deer, roe deer, wild pig.

by isolated finds of reindeer from Denmark and Schleswig-Holstein from the Allerød (CLAusen 2004) as well as a horse rib from Endingen VI (KaISER et al. 1999) and AMS-dated horse bones from Scania (Liljegren \& Ekström 1996). Further new faunal elements in Denmark in the (younger) Allerød are brown bear (Ursus arctos) and beaver (Castor fiber). Beaver is also present at the Federmesser site Alt-Duven- stedt LA 120B (Schleswig-Holstein) together with few burnt bones of fox and bird (CLAusen 2004). Birds and fish also were demonstrated at Endingen VI as remains of bones of grouse and pike (Kaiser et al. 1999). The large mammals indicate a faunal record with a combination of (surviving) open landscape and woodland species for the (early) Allerød.

If the faunal evidence of the Allerød from $\mathrm{N}$ 
Germany is compared with more southern areas, the latter show a remarkable greater variety of species. For example elements like red deer and roe deer are present in the Rhineland in the (younger) Allerød (cf. e.g. BaAles 1997). Red deer, roe deer and wild pig were (also) present in the rock shelters (abris) of the Leinebergland (STAEsche 1994). These finds demonstrate that a variety of woodland elements were typical for the faunal record in the Mittelgebirgszone close to the northern lowlands. A dog mandible from the Abri Bettenroder Berg dated to the late Allerød belongs to the early evidence of domesticated wolves, so that species might have occurred in the Lateglacial of N Germany as well. The earliest evidence for a dog from Mecklenburg-Vorpommern was detected at the Preboreal find layer of site Rothenklempenow (Benecke 2004).

With the start of the Younger Dryas at around $10800 \mathrm{BP} / 10800 \mathrm{cal}$. BC we can expect major changes of the environment (see above). Traditionally the fauna of the Younger Dryas is characterised by a dominance of reindeer: a lot of undated remains of that species from N Germany, Denmark, Scania and Bornholm probably date to that time (cf. e.g. BeneCKe 2000; Liljegren \& Ekström 1996; Casati et al. 2004). The well known archaeological site of Stellmoor in the Ahrensburg tunnel valley is completely dominated by reindeer bones (Krause \& Kollau 1943; Bratlund 1990). Recent AMS-dates of few warmer elements in the faunal record of Stellmoor indicate that these belong to a younger, Postglacial find layer that was not recognised during the Stellmoor excavation in the 1930s (BRATLUND 1999). It is possible that few elk remains from Stellmoor and the nearby site of Borneck belong to the Younger Dryas but a connection to the Postglacial has also to be taken into consideration (BENECKE 2004). More reliable evidence for presence of elk in the Younger Dryas comes especially from Scania where some horse re- mains and one elk find could be dated to the period between ca $11000-10500{ }^{14} \mathrm{C}$ years BP (Liljegren \& EKström 1996; Larsson et al. 2002). In addition probably wolf and different birds and fish were present in the Younger Dryas of N Germany (BeNeCKe 2004).

A ${ }^{14} \mathrm{C}$-plateau at the transitional period from the Younger Dryas to the Preboreal makes absolute dating difficult for that phase (JöRIs \& Weninger 2000), but we can propose that radiocarbon dates for the cold faunal record of Stellmoor places the find layer to the end of the Younger Dryas (Fischer \& TAuber 1986; BeNECKE 2004). The dominance of reindeer is an indication that the open environment persisted to the very end of this cold and dry period. The following climatic amelioration must have started short after this period and according to information from high resolution lacustrine archives this change must have been of quite dramatic character (RALSKA-JASIEWICZOWA et al. 2003).

There is increasing evidence that at the start of the Preboreal the fauna in N Germany and $S$ Scandinavia became more variable with elk, aurochs, wild pig and red deer (Fig. 6; BENECKE 2004). An isolated find of an aurochs from Potsdam-Schlaatz demonstrates successful hunting of that species (BENECKE 2002; 2004; GramsCH 2004). The most impressive example of successful hunting in the early Preboreal is represented by the deposits of elk bones from a kettle hole near Lundby bog on Zealand (Møller Hansen et al. 2004). Some faunal remains from aurochs, red deer and wild pig at this site might be somewhat younger. There are no sites in N Germany that prove the existence of reindeer in the faunal record of the Preboreal, although some individuals have to be expected: systematic radicarbon dating demonstrates that this species was still present in Scania in the early Preboreal (Liljegren \& Eкström 1996). 


\section{Human settlement}

The earliest settlement of N Germany and S Scandinavia is connected with the Hamburgian dated in the Bølling/Meiendorf. Basic knowledge on this hunter-gatherer technocomplex was obtained by excavations of the Meiendorf site in the 1930's (Rust 1937). Nowadays the Hamburgian can be divided into two groups: the early classical Hamburgian - characterised by shouldered points and known from several sites in Schleswig-Holstein - and a younger phase with Havelte points (Clausen 1997; ERIKSEN 2002). Recent discoveries support the idea that the early Hamburgian was possibly also present further to the north in Jutland (Holm 1996, 2003), which might indicate that hunters moved northward more rapidly than hitherto expected following the reindeers with seasonal camp moves only. But until now no site of the classical Hamburgian was found in the area glaciated during the Weichselian in NE Germany (Fig. 7a).

It is known for a long time that the Hamburgian with shouldered points is also present east of the river Oder (cf. Burdukiewicz \& Schmider 2000; ChŁlodnicki \& Kabacińnski 1997; KABACIŃNSKI personal communication). This confirms that the Hamburgian was widespread in the lowlands adjacent to the Mittelgebirgszone with the Magdalenian. Palynological information and ${ }^{14} \mathrm{C}$-dates from different areas indicate a reoccupation of the northern lowlands by the (early) Hamburgian with the climatic amelioration of the Meiendorf ca. $12600{ }^{14} \mathrm{C}$ years BP/ ca. 12600 cal. years BC (Fig. 8) (cf. Clausen 1997; Usinger 1997).

Against this background it is a question why the classical Hamburgian does not occur in NE Germany. Is it a gap of information or a gap of occupation? Recently Cziela (2001a) argued that isolated finds from Brandenburg that were previously interpreted as possible indications for the Hamburgian are questionable, and he poses the hypothesis that the missing evidence might be due to unfavourable living conditions. It is, however, well possible that the absence of Hamburgian sites in NE Germany is a gap of knowledge and research (Terberger 1996a; 1997). Isolated organic finds from Brandenburg like a worked reindeer antler from Großwusterwitz (nowadays lost) probably are elements of that phase. At the same time a Zinken from a site close to the Nebel valley north of Güstrow probably is a first indication for the Hamburgian in the Mecklenburg area (Fig. 7a,13) (Terberger 1997; Terberger \& LübKe 2004). If this assumption is correct a broad zone of (early) Hamburgian from the eastern to the western lowlands has to be expected. But it can be imagined that people avoided the Weichselian till plains in the early Hamburgian phase as is suggested by evidence from neighbouring areas. Then the (early) Hamburgian is restricted to more southern areas of Mecklenburg and Brandenburg.

New excavations at the Ahrenshöft site in northern Schleswig-Holstein for the first time gave clear evidence for a sequence of the classical Hamburgian and the Havelte phase (Clausen 1997). Palynological analysis dates the Havelte phase at Ahrenshöft in the later Bølling/Meiendorf around ca $12300-12000$ ${ }^{14}$ C years BP (Usinger 1997). Due to detections of the 1980s and 1990s Havelte sites are known from Jutland (HоLм 1996, 2003) and Zealand (Vang Petersen \& Johansen 1996; Johansen 2000; ERIKSEN 2002) and so they show a distribution from the Netherlands to the Danish islands. In contrast to the classical Hamburgian the Havelte sites have a distribution more in NW Europe and no evidence is found east of the river Oder (cf. Clausen 1997). Against this background it can be expected that Havelte sites occur at the eastern boarder of this technocomplex in NE Germany.

Although animal remains are only available from few sites these indicate dominance of rein- 


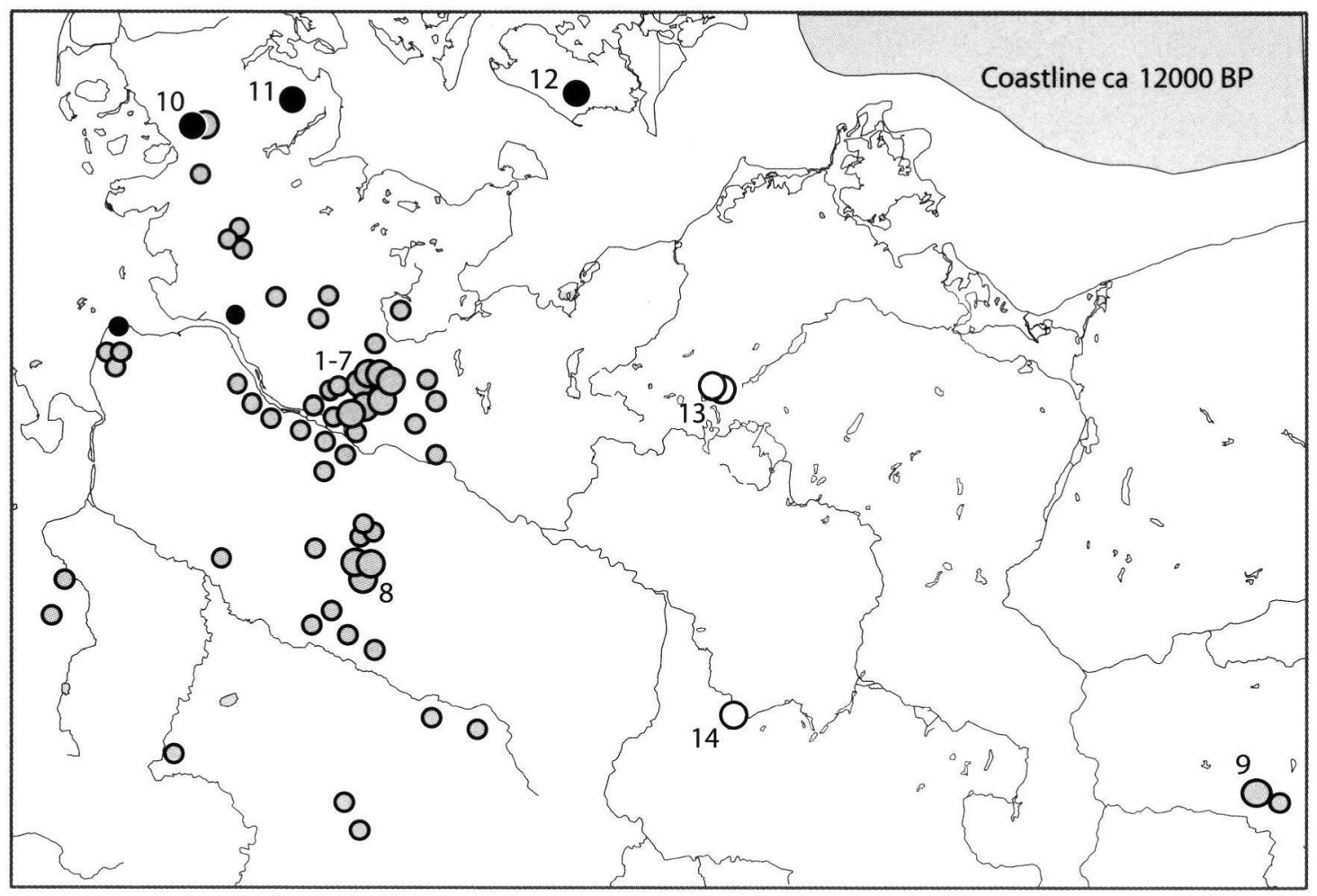

Fig. 7a: Site/find distribution of the Hamburgian (after Tromnau 1975; Clausen 1997). Grey circle: classical Hamburgian. - Black circle: Havelte sites. - Open circle: probable Hamburgian sites. More important sites: 1 Meiendorf. - 2 Borneck. - 3 Hasewisch. - 4 Stellmoor. - 5 Ahrensburg. - 6 Poggenwisch. - 7 Teltwisch. - 8 Deimern. - 9 Wojnowo. - 10 Ahrenshöft. - 11 Nübel. - 12 Sölbjerg. - 13 Lüssow Fp. 82. - 14 Großwusterwitz.

deer hunting for the Hamburgians. The used hunting weapons are still a matter of discussion: it is possible that the Hamburgian were the first people using bow and arrow for their hunt, as the slender Havelte point looks suitable as an arrow tip and as bones with embedded fragments of projectile points indicate shots with remarkable energy (BRatlund 1990; Holm 2003). It is proposed that Hamburgian sites are often connected with the migration routes of reindeers (Vang Peteresen \& Johansen 1996). Seasonal information from sites is so limited that it is not possible to develop a reliable settlement model for that time. It is discussed that the Hamburgian sites in Denmark represent only short visits and do not reflect a systematic use for a longer time (cf. ERIKSEN 2002).
At the beginning of the Allerød a general change took place in the environment and in people's way of life. The development of a birch-pine forest was connected with a fauna of woodland and open landscape elements. In general the raw material for the stone artefacts of the Federmesser technocomplex is of limited quality and the assemblages are characterised by a simpler blade technology with shorter and irregular blades. Short scrapers and Federmesser are typical elements and the backed points were probably used for arrow tips. Roe deer antler was also usually taken as organic raw material. Information on the Federmesser complex is mainly known from other areas (e.g. BAALES 2000; Pelegrin 2000; Fagnart \& Coudret 2000), 
but is limited in N Germany and S Scandinavia (Fig. 7b). Transfering information from other areas should be carried out with great care (JoHANSEN 2000; ERIKSEN 2002).

Two investigated elk hunter camps at the site Klein-Nordende CR in Schleswig-Holstein (Bokelmann et al. 1983) date the beginning of the Federmesser technocomplex around $12000{ }^{14} \mathrm{C}$ year BP/12000 cal. year BC which corresponds with the end of the Bølling/ Meiendorf and the transition to the Allerød, although an age of the humous find layer prior to the Allerød was discussed (BoKelmann et al. 1983). Possibly there is an overlap with the Havelte phase of the Hamburgian as Havelte points and Federmesser were found together in Ahrenshöft LA 58 (Clausen 1997). Site Alt Duvenstedt LA 120B (Schleswig-Holstein) contains a Federmesser inventory with faunal elements like beaver and fox; charcoal from a hearth is dated slightly younger around 11800 ${ }^{14} \mathrm{C}$ years BP (Clausen 2004).

The elk hunter site of Endingen VI (Vorpommern) was detected at the beginning of the $20^{\text {th }}$ Century (cf. Terberger 1996a; Street 1996). The faunal assemblage was AMS-dated to the early Allerød (Terberger 1996a; KaISER et al. 1999). Of special interest are a worked horse rib and a piece of giant deer antler. This find and a giant deer skull with traces of processing from W Mecklenburg suggest that giant deer was of some importance for hunting and as source of raw material (KAISER et al. 1999). Unfortunately no lithics were collected at Endingen VI. Though some surface sites with backed points exist (e.g. Berlekamp 1957), a more important Federmesser site was detected in Brandenburg (GramsCH 1969): a typical relatively small assemblage with backed points and a sand stone smoother was found here, organic remains were not preserved.

Finally a reindeer antler axe from SchleswigHolstein has to be mentioned that has been dated palynologically and by AMS-dating to

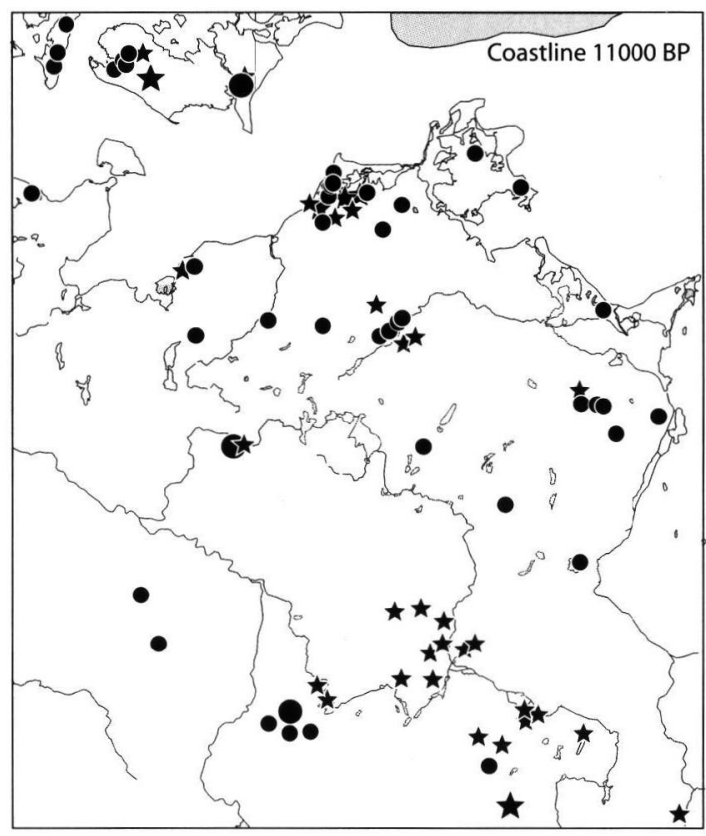

Fig. 7b: Federmesser (asteri) and Bromme point finds/ sites (circle) (after Taute 1968; Gramsch 1987; TERBERGER 1996b).

the Allerød (Clausen 2004). The find demonstrates that care is necessary in the schematic connection of "typical" implements with technocomplexes as the cultural context of the find is unclear at the moment.

In the later Allerød the early tanged point complex raises with the Brommean in S Scandinavia. Numerous sites with the typical large tanged points, scrapers and burins are known from Denmark and Scania that are interpreted as evidence of a year round exploitation (JoHANSEN 2000; Eriksen 2002). Few animal remains suggest that elk was the main hunting game. In N Germany comparable assemblages are known for a longer time that are assigned to the SegebroBromme-Gruppe and Tolk-Sprenge-Gruppe by TAUTE (1968). Geostratigraphical and palynological data date a find layer near Hamburg with Federmesser and Lyngby/ Bromme points to the later Allerød or slightly younger (SCHWABEDISSEN 1957; TAuTe 1968). This date was confirmed by an early radiocarbon date of around $11450{ }^{14} \mathrm{C}$ 
years BP of charcoal from the find layer. More recently discovered well-stratified Brommean sites are missing in N Germany. One should be cautious not to equate all finds of larger tanged points with the Brommean (Fig. 7b).

The Ahrensburgian is traditionally connected with reindeer hunters of the Younger Dryas. A closer view at the material shows that there are several tanged point finds (Fig. 7c) but only very few dated sites with rare faunal information. Without doubt well known sites like Stellmoor (upper find layer) actually date to the Younger Dryas. But excavations of the site Alt Duvenstedt LA 121 in Schleswig-Holstein show that the situation is more complicated. There a find layer with unquestionable Ahrensburgian finds was detected in a soil horizon that was interpreted to date from the Allerød (Clausen 1996a). Two ${ }^{14} \mathrm{C}$-dates obtained from charcoal gave results around $10800{ }^{14} \mathrm{C}$ years BP (Clausen 1996b). Calibration of these results (e.g. JörIs \& Weninger 2000) suggest a calendar age around $10850-10750 \mathrm{cal}$. years BC and a correlation with the very late part of the Allerød in the GRIP ice core chronology (Fig. 8). It should be stressed that Lateglacial soil formation processes should not be automatically linked to the Allerød, as the previous example of the Altdarss area demonstrates. In conclusion the evidence from Alt Duvenstedt LA 121 argues for the existence of an early Ahrensburgian in the late Allerød in NW Germany, probably parallel to the Brommean with large tanged points in Denmark.

It is likely that species like elk were typical faunal elements at that time. So the idea of reindeer hunting people with Ahrensburgian points emerging with the start of the Younger Dryas has to be questioned. On the background of these facts it is more probable that elk hunters of the late Allerød developed smaller tanged arrow points and formed the basis for the Ahrensburgian of the Younger Dryas.

There are other observations that show that care has to be taken in the connection of so called type fossils with special time periods, e.g. the reindeer antler axe from Klappholz mentioned above. Also results from direct AMS-dating of bone points from the northern lowlands show some differences compared to the expected ages: e.g. a point of Maglemosian character was dated to the Younger Dryas (Cziesla 2004).

Despite this new information it is in general correct to connect Ahrensburgian sites with the Younger Dryas. Probably most of the isolated reindeer remains of NE Germany date from this period. Several tanged point sites were found in the Saaler Bodden area, near Lake Kummerower See, near Stralsund, and in the Ueckermünde Heide area (Fig. 7c) (TAute 1968; Kaiser \& Terberger 1996; Terberger 1996b; Bogen et al. 2003). The topography of such sites is best illustrated with the situation near Verchen. The outflow of the river Peene from Lake Kummerow See nearly forms a peninsula where some sites are positioned close to the water on both sides of the river. The frequency of tanged points indicates intensive hunting activities, which probably took place during the migration seasons of reindeer in spring and/or autumn. Unfortunantely there are no organic finds available for AMS-dating.

A small tanged point inventory was excavated in the 1990s at the site Nienhagen (KaIser \& TerBERGER 1996; cf. Fig. 1). The assemblage was characterised by a heavy retouched large tanged point accompanied by small projectiles like a simple retouched point and a backed piece. The stratigraphic position of the find layer argues for a dating to the Younger Dryas. On typological evidence, however, some kind of affiliation with the Brommian industry cannot be ruled out.

The most reliable dates of the Ahrensburgian are derived at Stellmoor (upper find layer) in the Ahrensburg tunnel valley. The radiocarbon evidence for the site (Fischer \& TAuber 1986) with remains of more than 600 reindeers (Krause \& Kollau 1943; Bratlund 1990) 
points to a chronological position of the settlement phase at the very end of the Younger Dryas or the transition to the early Preboreal (Fig. 8). It is unfortunately still unclear how the dates from a fossil pond relate to the lithic assemblage from a neighbouring site. Possibly the large tanged points from Stellmoor belong to this late Younger Dryas occupation phase. The Stellmoor site might indicate that larger Ahrensburgian settlement sites developed in $\mathrm{N}$ Germany within a relatively short time-span at the end of the Younger Dryas.

Settlement evidence from the middle Younger Dryas is limited. Possibly people moved southward during very cold and dry phases and the northern regions might have been more or less abandoned for periods of time. This idea does not really contradict the model of a seasonal occupation of the Ahrensburgian sites with reindeer summer grazing areas in the Mittelgebirgszone and wintering areas in the north (BAALES 1996; Johansen \& Stapert 2000), but adds a more dynamic view on the ca. 1200 years of the Younger Dryas. The idea is supported by the fact that only very few tanged point finds are known from Dennmark (ERIKSEN 2002), whereas also the British peninsula saw only very restricted human activities (BARTON 2002; BARTON et al. 2003). Recently some faunal remains in Scania were identified that are connected with the presence of hunter groups (Larsson et al. 2002) and - though finds with clear traces of human activities is limited - indicate human presence in the late Allerød/ early Younger Dryas, the middle Younger Dryas, and in the late Younger Dryas/ early Preboreal. This is a further indication for episodes of presence in the northern areas during more favourable conditions (LARsSON et al. 2002).

Some assemblages with a long blade industry from $\mathrm{N}$ France and $\mathrm{S}$ Britain are assigned to the late Younger Dryas and/or the transition to the early Preboreal (cf. e.g. Barton 2002). These are characterised by very long blades that

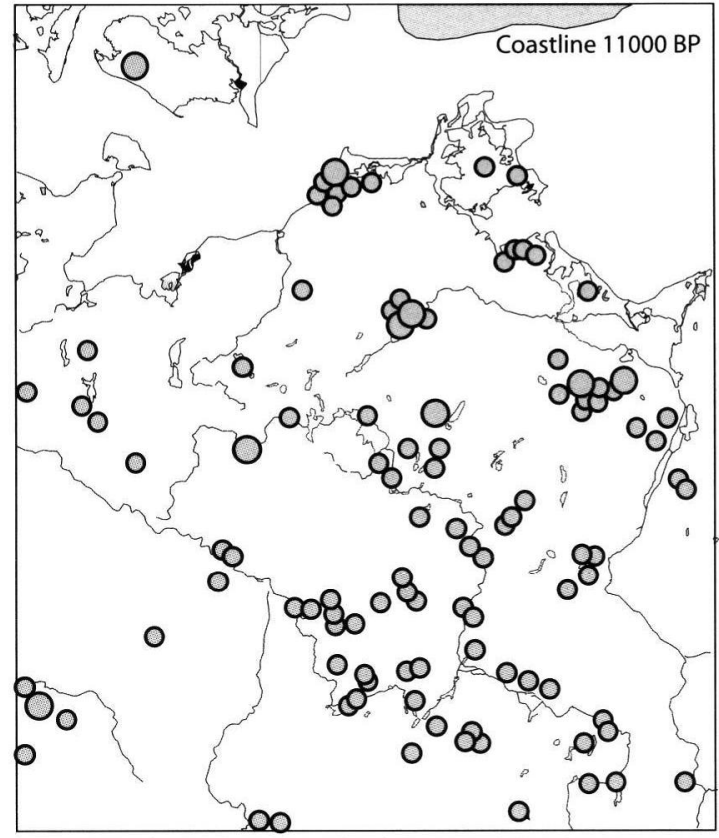

Fig. 7c: Ahrensburgian finds/ sites (after Terberger 1996b; Gramsch 1987; Cziesla 2001b).

often show signs of heavy use along the blade edges. These assemblages show similarities with the Eggstedt-Stellmoor-Gruppe of Taute (1968; cf. BaAles 1996; Barton 2002). Recently a lithic assemblage from Jutland was recognised with typical elements of a long blade industry ( $\varnothing \varnothing$ RENSEN \& STERnKe 2004). Although absolute dating of the site was not possible a connection with the Eggstedt-Stellmoor-Gruppe and long blade sites in NW Europe is very probable. Therefore it seems plausible to propose a comparable development of the assemblages in N Germany and S Scandinavia at the transition from the late Younger Dryas to the Holocene. The sites are normally connected with high quality flint sources. It still has to be cleared in more detail whether the long blade assemblages reflect only specialised flint workshops or whether they can also be interpreted in a chronological sense (cf. Barton 2002; Sørensen \& Sternke 2004). Unfortunateley there is very limited information available to characterise the subsistence strategy of these sites. 


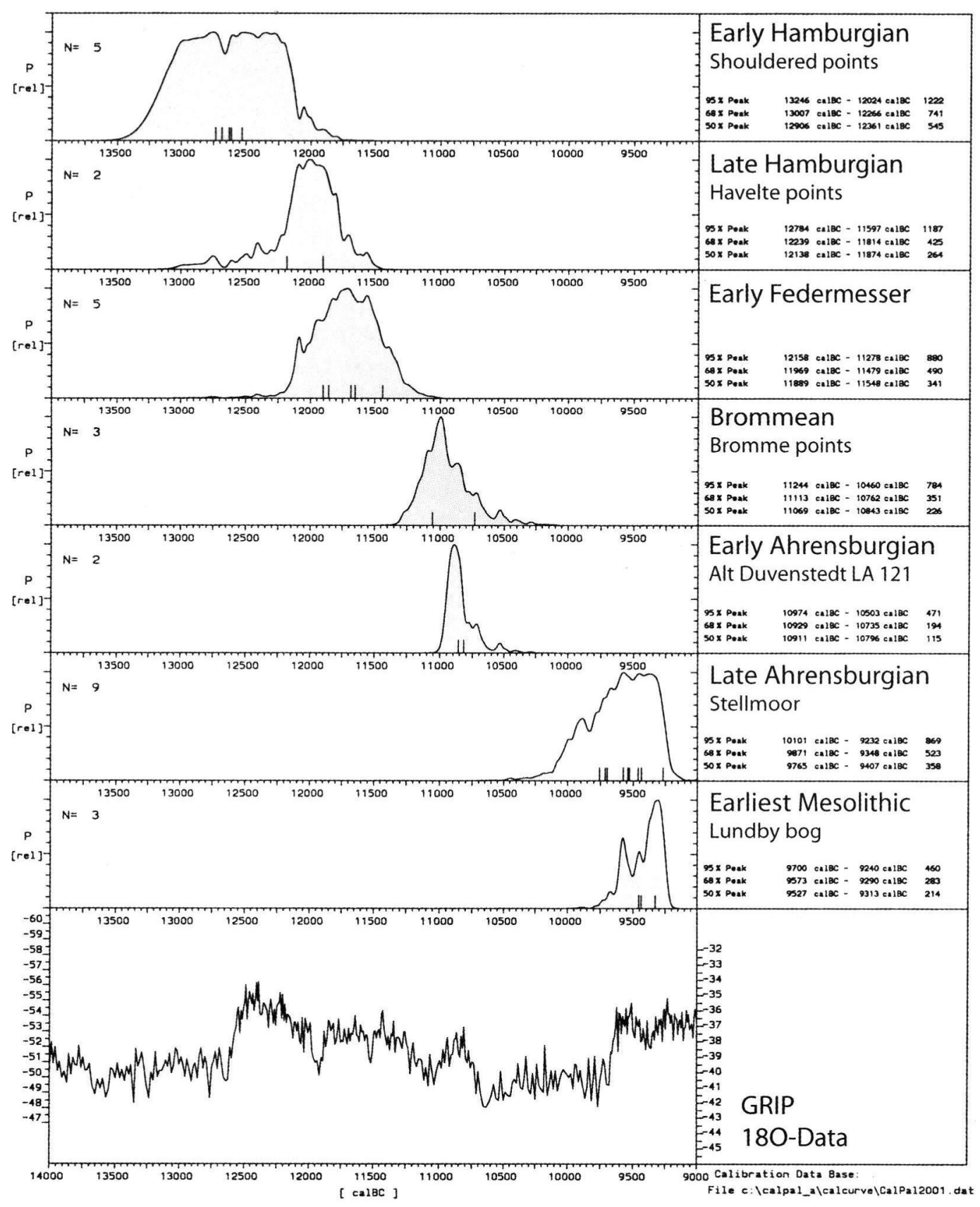

Fig. 8: Calibration of selected Lateglacial radiocarbon dates from N Germany and S Scandinavia. The calibration was conducted with the software Calpal by O. Jöris/ B. Weninger (Jöris \& WenINGer 2000; www.calpal.de). Note the broader probability curves for the early Hamburgian and the late Ahrensburgian as the consequence of larger wiggles in the calibration curve. The dates used for calibration are the following: Older Hamburgian/ Shouldered point assemblages (Fischer \& TAUber 1986; Holm 1996; Burdukiewicz 1999): Meiendorf - $12460 \pm 60$ BP (GrN-11254), $12360 \pm 110$ BP (K-4329); Poggenwisch $-12570 \pm 115$ BP (K-4332), $12440 \pm 115$ BP (K-4577); Slotseng - $12520 \pm 190$ BP (AAR-906). - Hamburgian, Havelte 
There is an ongoing debate whether there was a major population shift towards the north at the beginning of the Preboreal. It has been assumed that tanged point technocomplexes in Scandinavia that emerge at the very late Younger Dryas/ early Holocene originate from more southern areas (cf. e.g. TAUTE 1968; KINDGREN 1996). Recently Schild (2001) and KobusiewICZ (2004) presented arguments for the idea that new people were immigrating the Polish lowland at the beginning of the Mesolithic.

There is, however, increasing archaeological evidence from the transition to the Holocene and the early Preboreal. Sites such as the long blade assemblage mentioned above, the aurochs find from Potsdam-Schlaatz (BENECKe 2002) and the elk bone deposits from Lundby bog with ${ }^{14} \mathrm{C}$-dates of ca. $9950-9860 \mathrm{BP} / \mathrm{ca} .9600$ - 9250 cal.BC (Møller Hansen et al. 2004) suggest that people lived in N Germany and $S$ Scandinavia at that time (BENECKE 2002; 2004; Møller Hansen et al. 2004; Sørensen \& Sternke 2004; Terberger 2004; cf. Fig. 8). Of high relevance is the find assemblage from Lundby bog with an early Maglemosian character (Møller Hansen et al. 2004). An elk antler adze finds its parallels at the early Mesolithic site Star Carr and in the lower Mesolithc level of Friesack. This evidence is in some contradiction to the ideas of surviving "Epi-Ahrensburgian" (reindeer) hunter groups "during the first 500 years or so of the Holocene" (Johansen \& STAPERT 2000, p. 84).
Relying on the new information presented by Møller Hansen et al. (2004) an alternative model can be proposed for N Germany and $S$ Scandinavia: within a relatively short time-span - possibly only a few decades (RALSKa-JASIEWICzOWA et al. 2003) - a shift in the hunters prey from reindeer to aurochs and elk is recognisable. Simultaneously the stone knapping and projectile technology and the tool equipment show fundamental changes. Further information, however, is needed to better understand these changes and to answer the question whether they are indeed the consequence of new groups coming into the northern areas or whether a rapid adaptation (of parts) of the late Ahrensburgian hunter-gatherers took place.

\section{Integrated summary}

Figure 9 presents a summary of the main results presented in this paper.

A reliable chronology of events and processes still is absent for Mecklenburg-Vorpommern. The number of reliable ${ }^{14} \mathrm{C}$-dates is limited especially for the early Lateglacial, whereas those of the later Lateglacial mostly are of individual sections without direct palynological data. A correlation with high-resolution absolutely dated sections from other regions (such as annually laminated lake sediments or the Greenland ice-cores), therefore, is still a matter of hypothetical interpretation. Nevertheless a

phase (CLAuSEn 1998): Ahrenshöft LA $73-12200 \pm 60$ BP (KIA-3605); Ahrenshöft LA 58 - $12030 \pm 60$ BP (AAR-2784). - Federmesser (Clausen 1998; 2004; Terberger 1996b): Klein Nordende CR - $12035 \pm 110$ $\mathrm{BP}$ (KI-2124), $11990 \pm 100 \mathrm{BP}$ (KI-2152); Endingen - $11830 \pm 50 \mathrm{BP}$ (UtC-5681), $11555 \pm 100 \mathrm{BP}$ (UZ3798); Alt Duvenstedt LA 120B - $11780 \pm 110$ BP (AAR-2244). - Brommean (ERIKSEN 2002): Trollesgave - $11070 \pm 120$ BP (K-2641), $11100 \pm 160$ BP (K-2509); Bromme - $10720 \pm 90$ BP (AAR-4539). - Early Ahrensburgian (Clausen 2004): Alt Duvenstedt LA 121 - $10810 \pm 80$ BP (AAR-2245-1), $10770 \pm 60$ BP (AAR-2245-2). - Late Ahrensburgian (Fischer \& TAuber 1986): Stellmoor - $10110 \pm 105$ BP (K-4262), $9930 \pm 100$ BP (K-4323), $9900 \pm 105$ BP (K-4324), $10010 \pm 100$ BP (K-4325), $10140 \pm 105$ BP (K-4326), $10100 \pm 100$ BP (K-4578), $9980 \pm 105$ BP (K-4579), $9810 \pm 100$ BP (K-4580), $9990 \pm 105$ BP (K-4581). - Early Mesolithic (Møller Hansen et al. 2004): Lundby Bog - $9950 \pm 75$ BP (AAR-5469), $9939 \pm 70$ BP (AAR-5470), $9860 \pm 70$ BP (AAR-5471). 


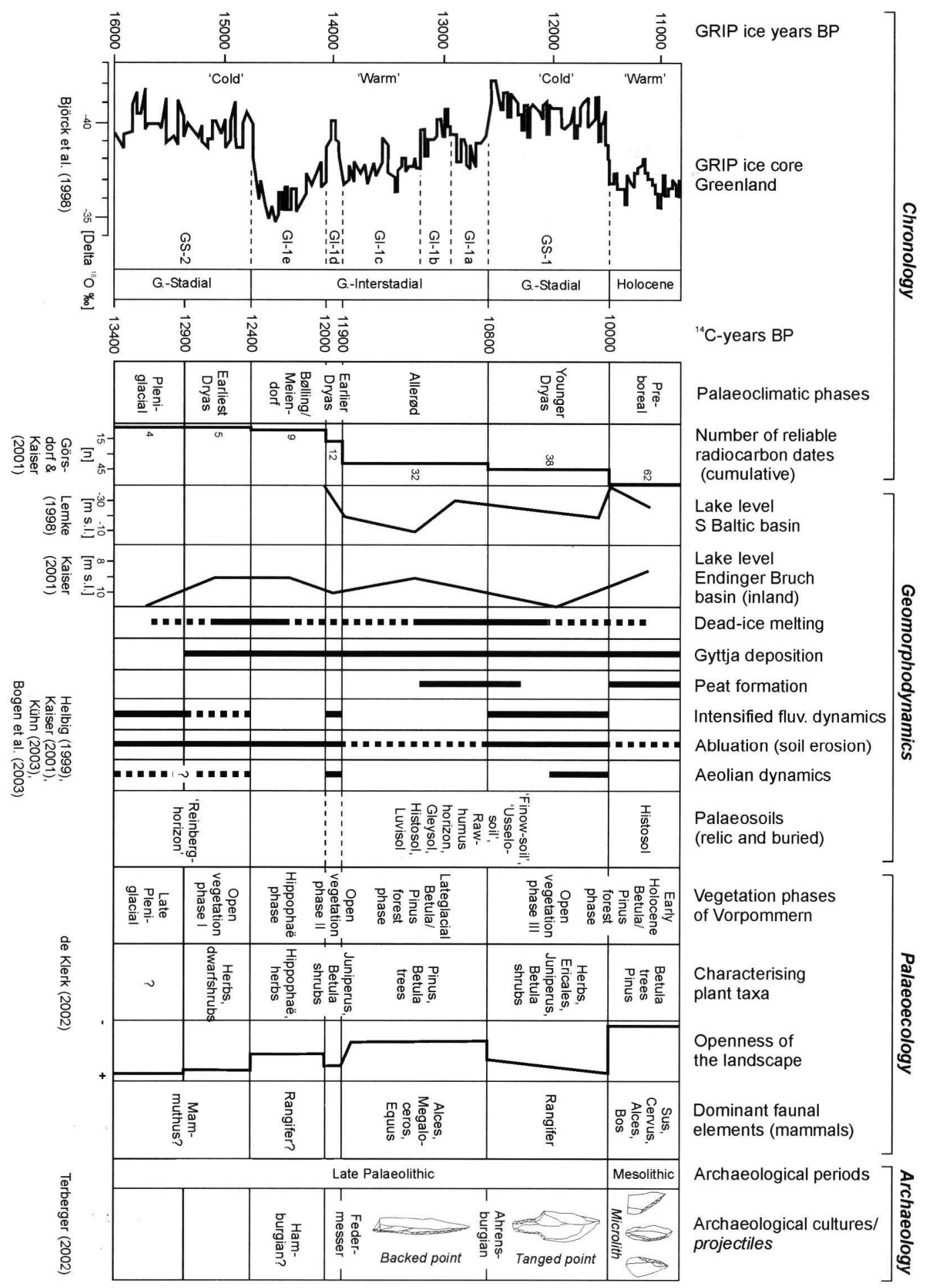

Fig. 9: Generalised summary of palaeoenvironmental and archaeological development in MecklenburgVorpommern. 
correlation of Lateglacial events and processes in Mecklenburg-Vorpommern with the oxygen isotope curve of the Greenland GRIP ice-core and the sequence of Greenland Stadials (GS) and Greenland Interstadials (GI) as proposed by BృörCK et al. (1998) is given. This is based on a preliminary correlation of the Greenland ice-core stratigraphy with the pollen diagram 'Hoher Birkengraben' (Fig. 5) presented by Billwitz et al. (2000). The chronology in ${ }^{14} \mathrm{C}$ years as presented in Fig. 9 bases on calibration with the program Calpal (see www.calpal.de) and slightly deviates from the (preliminary) chronology of the vegetation phases of Vorpommern as proposed by De KLERK (2002).

The knowledge on the environment and processes of the late Pleniglacial and early Lateglacial is still limited: especially the deglaciation processes of NE Germany between ca. 20000 and $14000{ }^{14} \mathrm{C}$ years $\mathrm{BP}$ is still badly dated. There is, however, an increasing amount of available data on the Lateglacial. Two pollen diagrams cover the earliest Lateglacial vegetation phases, whereas with the discovery of the 'Reinberg horizon' now the first known soil formation processes date at the transition from the Pleniglacial to the Lateglacial. Unfortunately too little data are available to say whether this is an exception or whether similar palaeosols also developed at other locations. A first phase of intensified dead-ice melting is placed in the Earliest Dryas and Bølling/Meiendorf. Soil erosion is high as consequence of the open vegetation; indication on Aaeolian activity, however, is limited. Also the knowledge on the dominant fauna in the Early Lateglacial still is limited. Though there is increasing evidence for the classical Hamburgian and the Havelte phase after ca. 12600 cal. years BC in NW Germany, Denmark and Poland, sites still are missing in MecklenburgVorpommern.

More data are available on the Allerød. Lake levels lowered and fluvial activity decreased. As consequence of the expansion of birch/ pine forests soil erosion decreased and mainly organic sediments deposited in basins. The development of peat layers was a consequence of increasing bioproduction under wet conditions, often in connection with a lowering of the lake level. A second phase of intensified dead-ice melting is proposed for this period. There are several observations of palaeosols that date in this phase. The earliest reliable evidence of human settlement is related with this period: elk shows to be the typical hunting game. Remains of giant deer and horse indicate the existence of open parts in the landscape.

Up to the beginning of the Younger Dryas Gleysols and Histosols have been prevalent in depressions. Arenosols (Regosols), weakly developed Podzols and Cambisols on sandy parent material as well as weakly developed Luvisols on till plains are common on sites not influenced by groundwater.

In the open landscape of the Younger Dryas soil erosion increased again, whereas fluvial dynamics enlarged. Lake levels predominantly rose and mainly clastic sediments were deposited. There are clear indications for increasing aeolian activity mainly in the second part of the Younger Dryas. A palaeosol in the Altdarss area was formed in an early phase of the Younger Dryas. Reindeer seems to be the predominant faunal element, but horse was also present. New information from $\mathrm{N}$ Germany suggests that the early Ahrensburgian industry developed in the late Allerød, but most Ahrensburgian sites belong to the Younger Dryas.

The transition to the Holocene shows a closing of forests, a lowering of water levels and the sedimentation of organic sediments as well as formation of peat. Soil erosion decreased. Probably the final melting of dead ice in NE Germany took place in the Preboreal. Remains of aurochs and elk indicate these animals as prominent faunal elements. New archaeological finds suggest a change of hunting species, material culture, and the way of living at that time. 


\section{Acknowledgements}

The investigations presented in this study were carried out in the late 1990 's by a multidisciplinary research group headed by Prof. Dr. Konrad Billwitz. The research was financed by the Deutsche Forschungsgemeinschaft (Projects Bi 560/1-3 "Chronostratigraphy of NE Germany" and Bi 560/1-5 "Specification of the earliest vegetation development at the site Reinberg (time slice I)" and the Federal State Mecklenburg Vorpommern (project EMAU 13$(95,96) 1997$ "Pollen- und Großrestanalytik"). B Lintzen and P. Wiese assisted in the preparation of some of the figures. We would like to thank A. Hilgers for the OSL-dates, and W. Dörfler and an anonymous reviewer for comments on the text.

\section{References}

Aaris-Sørensen, K. (1992): Deglaciation chronology and re-immigration of large mammals. A south Scandinavian example from late Weichselian - early Flandrian. In: von Koenigswald, W. \& Werdelin, L. (eds.): Mammalian Migration and Dispersal Events in the European Quaternary. - Courier Forschungsinstitut Senckenberg 153: 143-149; Frankfurt/ M.

Andres, W. \& Litt, T. (1999): Termination I in Central Europe. - Quaternary International, 61: 1-4; Oxford.

BAAles, M. (1996): Umwelt und Jagdökonomie der Ahrensburger Rentierjäger im Mittelgebirge.-Monographien des Römisch-Germanischen Zentralmuseums, 38; Mainz.

BaAles, M. (1997): Tierfährten in der allerødzeitlichen Vulkanasche des Laacher-See Vulkans bei Mertloch, Kreis MayenKoblenz. - Archäologisches Korrespondenzblatt, 27: 1-12; Mainz.

BaAles, M. (2000): L'archéologie du Paléolithi- que final en Rhénanie du centre et du nord (Allemagne). - In: Valentin, B., Bodu, P. \& Christensen, M. (eds.): L'Europe centrale et septentrionale au Tardiglaciaire. Confrontation des modèles régionaux de peuplement. Mémoires du Musée Préhistoire d'Ile de France, 7: 239-252; Nemours.

BARTON, R.N.E. (2002): Ensembles à pointes pédonculées du tardiglaciaire et technologies associées dans le sud de la GrandeBretagne. - In: Otтe, M. (ed.) : Préhistoire de la Grande Plaine du Nord de l'Europe. Actes du Colloque Chairte Francqui interuniversitaire au titre étranger, Liège juin 2001. ERAUL, 99: 69-81; Liège.

Barton, R.N.E., Jacobi, R.M., Street, M. \& Stapert, D. (2003): The Late-glacial reoccupation of the British Isles and the Creswellian. - Journal of Quaternary Science, 18: 1-13; New York.

Benre, K.-E. (1978): Die Klimaschwankungen im europäischen Präboreal. - Petermanns Geographische Mitteilungen, 122: 97-102; Gotha.

Benecke, N. (2000): Die jungpleistozäne und holozäne Tierwelt Mecklenburg-Vorpommerns. - Beiträge zur Ur- und Frühgeschichte Mitteleuropas, 23; Weissbach.

Benecke, N. (2002): Zur Neudatierung des Ur-Fundes von Potsdam-Schlaatz, Brandenburg. - Archäologisches Korrespondenzblatt, 32: 161-168; Mainz.

Benecke, N. (2004): Faunal succession in the lowlands of northern Central Europe at the Pleistocene - Holocene transition. - In: TERBerger, T. \& ERIKSEN, B. (eds.): Hunters in a changing world. Environment and archaeology of the Pleistocene - Holocene transition (ca. $11000-9000$ BC) in Northern Central Europe. International Archäologie Arbeitsgemeinschaft, Tagung, Symposium, Kongress. 5: 43-51; Rahden/ Westf.

Berlekamp, H. (1957): Spätpaläolithische Funde vom Saaler Bodden. - Ausgrabung 
und Funde, 2: 60-62; Berlin.

Billwitz, K., Helbig, H., Kaiser, K. \& Terberger, T. (1998): Geländebefunde zur spätglazialen Naturraumgenese und Besiedlungsgeschichte von Becken und Platten in Vorpommern. - Zeitschrift für Geomorphologie, N.F., Supplementband, 112: 123-142; Stuttgart.

Billwitz, K., Helbig, H., Kaiser, K., De Klerk, P., Kühn, P. \& Terberger, T. (2000): Untersuchungen zur spätpleistozänen bis frühholozänen Landschafts- und Besiedlungsgeschichte in Mecklenburg-Vorpommern. - Neubrandenburger Geologische Beiträge, 1: 24-38; Neubrandenburg.

Björck, S., Walker, M.J.C., Cwynar, L.C., Johnsen, S., Knudsen, K.-L., Lowe, J.J., Wohlfarth, B. \& Intimate Members (1998): An event stratigraphy for the Last Termination in the North Atlantic region based on the Greenland ice-core record: a proposal by the INTIMATE group. - Journal of Quaternary Science, 13: 283-292; New York.

Bock, W., Menke, B., Strehl, E. \& Ziemus, H. (1985): Neuere Funde des Weichselspätglazials in Schleswig-Holstein. - Eiszeitalter und Gegenwart, 35: 161-180; Stuttgart.

Bogen, C., Hilgers, A., Kaiser, K., Kühn, P. \& LiDKe, G. (2003): Archäologie, Pedologie und Geochronologie spätpaläolithischer Fundplätze in der Ueckermünder Heide (Kr. Uecker-Randow, Mecklenburg-Vorpommern). - Archäologisches Korrespondenzblatt, 33: 1-20; Mainz.

Bokelmann, K., Heinrich, D. \& Menke, B. (1983): Fundplätze des Spätglazials am Hainholz-Esinger Moor, Kreis Pinneberg.Offa, 40: 199-240; Kiel.

Böse, M. (1991): A palaeoclimatic interpretation of frost-wedge casts and aeolian sand deposits in the lowlands between Rhine and Vistula in the Upper Pleniglacial and Late Glacial. - Zeitschrift für Geomorphologie N.F., Sup- plement Band, 90: 15-28; Stuttgart.

Bramer, H. (1961): Über Vorkommen von Löss in der Umgebung von Pasewalk. - Geographische Berichte, 6: 241-246; Berlin.

Bramer, H. (1975): Über ein Vorkommen von Alleröd-Torf in Sedimenten der Ueckermünder Heide. - Wissenschaftliche Zeitschrift der Ernst-Moritz-Arndt-Universität Greifswald, Mathematisch-naturwissenschaftliche Reihe, 24 (3/4): 11-15; Greifswald.

Bratlund, B. (1990): Rentierjagd im Spätglazial. Eine Untersuchung der Jagdfrakturen an Rentierknochen von Meiendorf und Stellmoor. - Offa, 47: 7-34; Kiel.

Bratlund, B. (1999): A revision of the rarer species from the Ahrensburgian assemblage of Stellmoor. In: BenECKE, N. (ed.), The Holocene History of the European Vertebrate Fauna. - Archäologie in Eurasien, 6: 39-42; Rahden/ Westf.

Burdukiewicz, J.M. (1999): Concerning chronology of the Hamburgian culture.Folia Quaternaria, 70: 127-146; Kraków.

Burdukiewicz, J.M. \& Schmider, B. (2000): Analyse comparative pointes à cran hambourgiennes du Bassin de l'oder et des pointes à magdaléniennes du Bassin parisien. - In: Valentin, B., Bodu, P. \& Christensen, M. (eds.) : L'Europe centrale et septentrionale au Tardiglaciaire. Confrontation des modèles régionaux de peuplement. Mémoires du Musée Préhistoire d'Ile de France, 7: 97-108; Nemours.

Bussemer, S. (2002): Periglacial cover-beds in the young moraine landscapes of northern Eurasia - Zeitschrift f. Geomorphologie, Supplementband, 127: 81-105; Stuttgart.

Bussemer, S., Gärtner, P. \& SchlaAk, N. (1998): Stratigraphie, Stoffbestand und Reliefwirksamkeit der Flugsande im brandenburgischen Jungmoränenland. - Petermanns Geographische Mitteilungen, 142: 115-125; Gotha.

Casati, C., Sørensen, L. \& Vennersdorf, 
M. (2004): Current research of the Early Mesolithic on Bornholm, Denmark. - In: Terberger, T. \& Eriksen, B. (eds.): Hunters in a changing world. Environment and archaeology of the Pleistocene - Holocene transition (ca. 11000 - 9000 B.C.) in Northern Central Europe. Internationale Archäologie - Arbeitsgemeinschaft, Tagung Symposium, Kongress, 5: 113-132; Rahden/ Westf.

Caspers, G. \& Schwarz, C. (1998): Fluviatile und äolische Prozesse im Gebiet der unteren Elbe bei Neuhaus (Niedersachsen) seit dem Weichsel-Spätglazial. - Mitteilungen des Geologischen Institutes der Universität Hannover, 38: 49-64; Hannover.

ChŁlodnicki, M. \& Kabacińnski, J. (1997): Mirkowice - another seettlement site of the hamburgian culture at the Polish plain. - Przegląd Archeologiczny, 45: 5-24; Wrockaw.

Снвовок, S. M. \& Nitz, B. (1995): A remarkable series of Late-glacial sediments in the hinterland of the Frankfurt end moraine, north of Berlin. - In: Ehlers, J., Kozarski, S. \& Gibbard, P. (eds.): Glacial deposits in North-East Europe: 493-500; Rotterdam (Balkema).

Clausen, I. (1996a): Alt Duvenstedt LA 121, Schleswig-Holstein - Occureence of the Ahrensburgian Culture in soils of the Alleröd Interstadial. A Preliminary Report. - In: Larsson, L. (ed.): The Earliest Settlement of Scandinavia and ith relationship with neighbouring areas. Acta Archaeologica Lundensia Series, 8/24: 99-110; Stockholm.

Clausen, I. (1996b): Alt-Duvenstedt, Kr. Rendsburg-Eckernförde. - Offa, 53: 372373; Kiel.

Clausen, I. (1997): Neue Untersuchungen an späteiszeitlichen Fundplätzen der Hamburger Kultur bei Ahrenshöft, Kr. Nordfriesland (ein Vorbericht). - Archäologische Nachrichten aus Schleswig-Holstein, 8:

\section{8-49; Schleswig.}

Clausen, I. (2004): The Reindeer antler axe of the Allerød period from Klappholz LA 63, Kreis Schleswig-Flensburg/ Germany. Is it a relict of the Federmesser, Bromme or Ahrensburg Culture? - In: Terberger, T./ ERIKSEN, B. V. (eds.): Hunters in a changing world. UISPP commission XXXII, Workshop Greifswald September 2002. Internationale Archäologie - Arbeitsgemeinschaft, Symposium, Tagung, Kongress, 5: 141-164; Rahden/Westf.

Coope, G.R. \& LemdahL, G. (1995): Regional differences in the Lateglacial climate of northern Europe based on coleopteran analysis. - Journal of Quaternary Science, 10: 391-395; Chichester.

Cziela, E. (2001a): Zur Besiedlungsgeschichte von Berlin-Brandenburg: Die Anfänge. In: Gehlen, B., Heinen M. \& Tillmann, A. (eds.): Zeit-Räume. Gedenkschrift für Wolfgang Taute. Archäologische Berichte, 14: 381-396; Bonn.

Cziela, E. (2001b): Eine Verbreitungskarte zu den Stielspitzengruppen in Berlin und Brandenburg. - Fontes Archaeologici Posnaniensis, 39: 47-53; Poznań.

Cziela, E. (2004): Late Upper Palaeolithic and Mesolithic cultural continuity - or: bone and antler objects from the Havelland. - In: Terberger, T./ Eriksen, B. V. (eds.): Hunters in a changing world. UISPP commission XXXII, Workshop Greifswald September 2002. Internationale Archäologie - Arbeitsgemeinschaft, Symposium, Tagung, Kongress, 5: 165-182; Rahden/Westf.

De KLerk, P. (2002): Changing vegetation patterns in the Endinger Bruch area (Vorpommern, NE Germany) during the Weichselian Lateglacial and Early Holocene. - Review of Palaeobotany and Palynology, 119: 275-309; Amsterdam.

De Klerk, P. (2004 a): Changes in vegetation and environment at the Lategla- 
cial- Holocene transition in Vorpommern (NE Germany). - In: Terberger, T. \& ErIKsen, B. (eds.): Hunters in a changing world. Environment and archaeology of the Pleistocene - Holocene transition (ca. 11000 - 9000 B.C.) in Northern Central Europe. Internationale Archäologie - Arbeitsgemeinschaft, Tagung Symposium, Kongress, 5; Rahden/Westf.

De Klerk, P. (2004 b): Confusing concepts in Lateglacial stratigraphy and geochronology: origin, consequences, conclusions (with special emphasis on the type locality Bøllingsø). - Review of Palaeobotany and Palynology, 129: 265-298; Amsterdam.

De Klerk, P. \& Stolze, S. (2002): Unterschiede in Vegetation und Sedimentation zwischen N-Vorpommern und S-Mecklenburg: Ein spätglazialer Klimagradient? - Greifswalder Geographische Arbeiten, 26: 161-165; Greifswald.

De Klerk, P., Helbig, H, Helms, S., Janke, W., Krügel, K., Kühn, P., Michaelis, D. \& Stolze, S. (2001): The Reinberg researches: Palaeoecological and geomorphological studies of a kettle hole in Vorpommern (NE Germany), with special emphasis on a local vegetation during Weichselian Pleniglacial/ Lateglacial transition. - Greifswalder Geographische Arbeiten, 23: 43-131; Greifswald.

De Klerk, P., Janke, W., Kühn, P. \& Theuerkauf, M. (submitted): Palaeo-environmental processes around the deposition of the Laacher See tephra in the distal area of its north-eastern fan: an example from the Reinberg basin (Vorpommern, NE Germany). - Quaternary Science Reviews; Oxford.

Dijkmans, J.W.A. (1989): Frost wedges in an eolian sand sheet near Sondre Stromfjord, W. Greenland and their paleoenvironmental implications. - Zeitzschrift f. Geomorph., N.F., 33/3: 339-353; Stuttgart.

ERIKSEN, B.V. (1996): Regional Variation in
Late Pleistocene Subsistence Strategies. Southern Scandinavian Reindeer Hunters in a European Context. - In: Larsson, L. (ed.): The Earliest Settlement of Scandinavia and its relationship with neighbouring areas. Acta Archaeologica Lundensia Series, 8/24: 7-22; Stockholm.

ERIKSEN, B.V. (2002): Reconsidering the geochronological framework of Lateglacial hunter-gatherer colonization of southern Scandinavia. - In: Eriksen, B.V. \& Bratlund, B. (eds.): Recent studies in the Final Palaeolithic of the European plain. Proceedings of a U.I.S.P.P. Symposium, Stockholm, 14.-17. October 1999. Jutland Archaeological Society Publications, 39: 25-41; Højbjerg.

FAO 1998: World Reference Base for Soil Resources. - FAO, World Soil Resources Report, 84. 88 S.; Rome.

Fagnart, J.P. \& Coudret, P. (2000): Le Tardiglaciaire dans le Nord de la France. - In: B. Valentin, P. Bodu \& M. Christensen (eds.): L'Europe centrale et septentrionale au Tardiglaciaire. Confrontation des modèles régionaux de peuplement. Mémoires du Musée Préhistoire d'Ile de France, 7:111128; Nemours.

Fischer, A. \& Tauber, H. (1986): New C-14 Datings of Late Palaeolithic Cultures from Northwestern Europe. - Journal of Danish Archaeology, 5: 7-13; Odense.

GöRSDORF, J. \& KAISER, K. (2001): Radiokohlenstoffdaten aus dem Spätpleistozän und Frühholozän von Mecklenburg-Vorpommern. - Meyniana, 53: 91-118; Kiel.

Gramsch, B. (1969): Ein Lagerplatz der Federmesser-Gruppe bei Golßen, Kr. Luckau. - Ausgrabung und Funde, 14: 121128; Berlin.

Gramsch, B. (1987): The Late Palaeolithic in the area lying between the river Oder and rhe Elbe/ Havel. - In: Burdukiewicz, J.M./ Kobusiewicz, M. (eds.): Late Glacial in 
Central Europe - Culture and Environment. Prace Komisji Archeologicznej, 5: 107-120; Wrocław.

Gramsch, B. (2004): From the Late Palaeolithic to the early Mesolithic in north-eastern Germany. - In: Terberger, T./ Eriksen, B.V. (eds.): Hunters in a changing world. UISPP commission XXXII, Workshop Greifswald September 2002. Internationale Archäologie - Arbeitsgemeinschaft, Tagung Symposium, Kongress, 5: 183-202; Rahden/ Westf.

Helbig, H. (1999a): Die spätglaziale und holozäne Überprägung der Grundmoränenplatten in Vorpommern. - Greifswalder Geographische Arbeiten, 17. 110 S.; Greifswald.

Helbig, H. (1999b): Die periglaziäre Überprägung der Grundmoränenplatten in Vorpommern. - Petermanns Geographische Mitteilungen, 143(5/6): 373-386; Gotha.

Helbig, H. \& De Klerk, P. (2002): Befunde zur spätglazialen fluvial-limnischen Morphodynamik in kleinen Talungen Vorpommerns. - Eiszeitalter und Gegenwart, 51: 51-66; Hannover.

Hoek, W.Z. (1997): Palaeogeography of Lateglacial vegetations. Aspects of Lateglacial and Early Holocene vegetation, abiotic landscape, and climate in The Netherlands. - Nederlandse Geografische Studies, 230: 1-147; Utrecht.

Hoek, W.Z. (2001): Vegetation response to the -14.7 and $-11.5 \mathrm{ka}$ cal. BP climate transitions: is vegetation lagging climate? Global and planetary change, 30: 103-115; Amsterdam.

Hoffmann, R.; Blume, H.P. (1977): Holozäne Tonverlagerung als profilprägender Prozeß lehmiger Landböden norddeutscher Jungmoränenlandschaften? - Catena, 4: 359368; Gießen.

Holm, J. (1996): The Earliest Settlement of Denmark. - In: Larsson, L. (ed.): The Earliest Settlement of Scandinavia and its relationship with neighbouring areas. Acta Archaeologica Lundensia Series, 8/24: 4359; Stockholm.

Holm, J. (2003): Rentierjäger im Norden. - Archäologie in Deutschland, 2003/3: 54-56; Stuttgart.

IsARIN, R.F.B. (1997): The climate in north-western Europe during the Younger Dryas: A comparison of multi-proxy climate reconstructions with simulation experiments. - Nederlandse Geografische Studies, 229: 1-160; Utrecht.

ISARIN, R.F.B. \& BOHNCKe, S.J.P. (1999): Mean july temperatures during the Younger Dryas in northwestern and central Europe as inferred from climate indicator plant species. - Quaternary Research, 51: 158-173. Orlando.

Issmer, K. (1999): Plenivistulian and Late Vistulian loess deposits in northwestern Poland (Western Pomerania). - GeoArchaeoRhein, 3: 83-96; Münster.

JANKE, W. (2002): The development of the river valleys from the Uecker to the Warnow.Greifswalder Geographische Arbeiten, 27: 101-106; Greifswald

Johansen, L. (2000): The Late Palaeolithic in Denmark. - In: Valentin, B., Bodu, P. \& Christensen, M. (eds.): L'Europe centrale et septentrionale au Tardiglaciaire. Confrontation des modèles régionaux de peuplement. Mémoires du Musée Préhistoire d'Ile de France, 7: 197-215; Nemours.

Johansen, L. \& STAPert, D. (2000): Two 'Epi-Ahrensburgian' sites in the northern Netherlands: Oudehaske (Friesland) and Gramsbergen (Overijssel). - Palaeohistoria, 39/40, 1997/1998 (2000): 1-87; Lisse.

JöRIS, O. \& WENINGER, B. (2000): Radiocarbon calibration and the absolute chronology of the Late Glacial. - In: Valentin, B., Bodu, P. \& Christensen, M. (eds.): L'Europe centrale et septentrionale au tardiglaciaire: confrontation des modèles régionaux de peuplement. Mémoires du Musée Préhistoire d'Ile 
de France, 7: 19-54; Nemours.

KaIser, K. (1996): Zur hydrologischen Entwicklung mecklenburgischer Seen im jüngeren Quartär. - Petermanns Geographische Mitteilungen, 140: 323-342; Gotha.

KaIser, K. (2001): Die spätpleistozäne bis frühholozäne Beckenentwicklung in Mecklenburg-Vorpommern - Untersuchungen zur Stratigraphie, Geomorphologie und Geoarchäologie.- Greifswalder Geographische Arbeiten, 24. 208 S.; Greifswald.

KaIsER, K. (ed.) (2002): Die jungquartäre Flußund Seegenese in Nordostdeutschland. - Greifswalder Geographische Arbeiten, 26: 243 S.; Greifswald.

KaIser, K. (2004 a): Geomorphic characterization of the Pleistocene-Holocene transition in NE Germany. - In Terberger, T. \& ErIKsen, B.V. (eds.): Hunters in a changing world UISPP commission XXXII, Workshop Greifswald September 2002. Internationale Archäologie - Arbeitsgemeinschaft, Tagung Symposium, Kongress, 5: 53-73; Rahden/ Westf.

Kaiser, K. (2004 b): Lake basin development in the Endinger Bruch area (Vorpommern, NE Germany) during the Late Pleistocene and Early Holocene. - Zeitschrift für Geomorphologie N.S. 48: 461-480; Stuttgart.

Kaiser, K. \& JANKe, W. (1998): Bodenkundlich-geomorphologische und paläobotanische Untersuchungen im Ryckbecken bei Greifswald. - Bodendenkmalpflege in Mecklenburg-Vorpommern, 45, Jahrbuch 1997 (1998): 69-102; Lübstorf.

Kaiser, K. \& Terberger, T. (1996): Archäologisch-geowissenschaftliche Untersuchungen am spätpaläolithischen Fundplatz Nienhagen, Lkr. Nordvorpommern. - Bodendenkmalpflege in Mecklenburg-Vorpommern, 43, Jahrbuch 1995: 7-48; Lübstorf.

Kaiser, K., De Klerk, P. \& Terberger, T. (1999): Die „Riesenhirschfundstelle“ von Endingen: geowissenschaftliche und ar- chäologische Untersuchungen an einem spätglazialen Fundplatz in Vorpommern.Eiszeitalter und Gegenwart, 49: 102-123; Hannover.

Kaiser, K., Bogen, C., Czakó-Pap, S. \& JANKE, W. (2003): Zur Geoarchäologie des mesolithisch-neolithischen Fundplatzes Rothenklempenow am Latzigsee in der Ueckermünder Heide (Vorpommern).- Greifswalder Geographische Arbeiten, 29: 27-56; Greifswald.

Kaiser, K., Schoknecht, T., Janke, W., Kloss, K. \& Prehn, B. (2002): Geomorphologische, palynologische und archäologische Beiträge zur holozänen Landschaftsgeschichte im Müritzgebiet (Mecklenburg-Vorpommern).- Eiszeitalter und Gegenwart, 51: I 5-32; Hannover.

Kaiser, K, Barthelmes, A., Czakó Pap, S., Hilgers, A., Janke, W., KüHn, P. \& Theuerkauf, M. (submitted): A Lateglacial palaeosoil cover in the Altdarss area, southern Baltic coast (NE Germany): investigations on pedology, geochronology, and palaeobotany. - Eiszeitalter und Gegenwart; Hannover.

Kasse, C. (1999): Late Pleniglacial and Late Glacial aeolian phases in The Netherlands. GeoArchaeoRhein, 3: 61-82; Münster.

Kindgren, H. (1996): Reindeer or seals? Some Late Palaeolithic sites in central Bohuslän.- In: Larsson, L. (ed.), The Earliest Settlement of Scandinavia and ith relationship with neighbouring areas. Acta Archaeologica Lundensia Series, 8/24: 191-205; Stockholm.

Kliewe, H.; Schultz, H.-J. (1970): Die periglaziäre Fazies im Jungmoränengebiet nördlich der Pommerschen Eisrandlage. - In: Richter, H.; HaAse, G., Lieberoth, I. \& Ruske, R. (Hrsg.): Periglazial-Löß-Paläolithikum im Jungpleistozän der DDR: 255-263; Gotha.

Kobusiewicz, M. (2004): The problem of the 
Palaeolithic - Mesolithic transition on the Polish Plain: state of research. - In: TerBERger, T. \& ERIKSEN, B.V. (eds.): Hunters in a changing world. UISPP commission XXXII, Workshop Greifswald September 2002. Internationale Archäologie - Arbeitsgemeinschaft, Tagung Symposium, Kongress, 5: 133-140; Rahden/Westf.

Kolstrup, E. (1979): Herbs as july temperature indicators for parts of the pleniglacial and late-glacial in the Netherlands. - Geologie en Mijnbouw, 58: 377-380; Utrecht.

Kolstrup, E. (1991): Danish Weichselian and Holocene aeolian deposits an their environment: a preliminary account. - Zeitschrift für Geomorphologie N.F., Supplement Band, 90: 89-97; Stuttgart.

Kopp, D. (1970): Periglaziale Umlagerungs(Perstruktions-)zonen im nordmitteleuropäischen Tiefland und ihre bodengenetische Bedeutung. - Tagungsberichte Dt. Akademie Landwirtschaftswissenschaften, 102: 55-81; Berlin.

KozARski, St. (1974): Evidences of Late-Würm Permafrost occurrence in Northwest Poland. - Quaestiones Geographicae, 1: 65-86; Poznań.

Krause, W. (1937): Die eiszeitlichen Knochenfunde von Meiendorf. - In Rust, A.: Das altsteinzeitliche Rentierjägerlager Meiendorf: 48-61; Neumünster.

Krause, W. \& Kollau, W. (1943): Die steinzeitlichen Wirbeltierfaunen von Stellmoor in Holstein. - In: Rust, A.: Die alt- und mittelsteinzeitlichen Funde von Stellmoor; Neumünster.

KüHN, P. (2001): Grundlegende Voraussetzungen bodengenetischer Vergleichsuntersuchungen: Theorie und Anwendung.Greifswalder Geographische Arbeiten, 23: 133-153; Greifswald.

KüHN, P. (2003a): Spätglaziale und holozäne Lessivégenese auf jungweichselzeitlichen Sedimenten Deutschlands. - Greifswalder
Geographische Arbeiten, 28: 1-167; Greifswald.

KüHN, P. (2003b): Micromorphology and Late Glacial/Holocene Genesis of Luvisols in Mecklenburg-Vorpommern (NE-Germany).- Catena, 54. 537-555; Amsterdam.

Kühn, P., Janetzko, P. \& Schröder, D. (2002): Zur Mikromorphologie und Genese lessivierter Böden im Jungmoränengebiet Schleswig-Holsteins und Mecklenburg-Vorpommerns. - Eiszeitalter und Gegenwart, 51: 74-92; Hannover.

Larsson, L., Liljegren, R., Magnell, O. \& Екsтröм, J. (2002): Archaeo-faunal aspects of bog finds from Hässleberga, southern Scania, Sweden. - In: Eriksen, B.V. \& Bratlund, B. (eds.): Recent studies in the Final Palaeolithic of the European plain. Proceedings of a U.I.S.P.P. Symposium, Stockholm, 14.-17. October 1999. Jutland Archaeological Society Publications, 39: 6174; Højbjerg.

LemKe, W. (1998): Sedimentation und paläogeographische Entwicklung im westlichen Ostseeraum (Mecklenburger Bucht bis Arkonabecken) vom Ende der Weichselvereisung bis zur Litorinatransgression. - Meereswissenschaftliche Berichte, 31: 156 S.; Warnemünde.

Liljegren, R. \& Ekström, J. (1996): The Terrestrial Late Glacial Fauna in South Sweden.- In: Larsson, L. (ed.), The Earliest Settlement of Scandinavia and its relationship with neighbouring areas. Acta Archaeologica Lundensia Series, 8/24: 135-139; Stockholm.

LitT, T. (2003): Environmental response to climate and human impact in central Europe during the last 15,000 years - a German contribution to PAGES-PEPIII. - Quaternary Science Reviews, 22: 1-4; Amsterdam.

Litt, T. \& Stebich, M. (1999): Bio- and chronostratigraphy of the lateglacial in the Eifel region, Germany. - Quaternary Interna- 
tional, 61: 5-16; Amsterdam.

Litt, T., Brauer, A., Goslar, T., Merkt, J., Balaga, K., Müller, H., Ralska-Jasiewiczowa, M., Stebich, M.\& Negendank, J.F.W. (2001): Correlation and synchronisation of Lateglacial continental sequences in northern central Europe based on annually laminated lacustrine sediments. - Quaternary Science Reviews, 20: 1233-1249; Oxford.

Lorenz, S. (2003): Geomorphogenese, Sedimente und Böden der Terrassen am Krakower See in Mecklenburg - Untersuchungen zur jungquartären Paläohydrologie. - Greifswalder Geographische Arbeiten, 29: 57-92; Greifswald.

Lowe, J.J., Gray, J.M., (1980): The stratigraphic subdivision of the Lateglacial of NW Europe: a discussion. - In: Lowe, J.J., Gray, J.M., Robinson, J.E. (eds.): Studies in the lateglacial of North-west Europe. Including papers presented at a symposium of the Quaternary Research Association held at University College London, January 1979: 157-175; Oxford.

Ludwig, A. O. (2002): Die spätglaziale Entwicklung im östlichen Küstengebiet Mecklenburgs (Rostocker Heide, Fischland).Greifswalder Geographische Arbeiten, 26: 83-86; Greifswald.

Mackay, J.R. (1993): Air temperature, snow cover, creep of frozen ground and the time of ice-wedge cracking, western Arctic coast. - Canadian Journal of Earth Sciences, 30: 1720-1729; Ottawa.

Mangerud, J., Andersen, S.T., Berglund, B.E. \& Donner, J.J. (1974): Quaternary Stratigraphy of Norden, a proposal for terminology and classification. - Boreas, 3: 109-128; Oslo.

Manikowska, B. (1991): Vistulian and Holocene Aeolian activitiy, pedostratigraphy and relief evolution in Central Poland.- Zeitschrift für Geomorphologie,
N.F., Suppl.-Bd., 90: 131-141; Stuttgart.

Menke, B. (1968): Das Spätglazial von Glüsing. Ein Beitrag zur Kenntnis des spätglazialen Vegetationsgeschichte in Westholstein. - Eiszeitalter und Gegenwart, 19: 73-84; Öhringen.

Müller, U., Rühberg, N. \& Krienke, H.-D. (1995): The Pleistocene sequence in Mecklenburg-Vorpommern. - In: EHLERs, J., Kozarski, S. \& Gibbard, P. (eds.): Glacial deposits in North-East Europe: 501-514; Rotterdam (Balkema).

Murton, J.B. (1996): Morphology and paleoenvironmental significance of quaternary sand veins, sand wedges, and composite wedges, Tuktoyaktuk Coastlands, Western Arctic Canada. - Journal of Sedimentary Research, 66: 17-25; Oxford.

Murton, J.B. \& French, H.M. (1993): Thaw modification of frost-fissure wedges, Richard Islands, Pleistocene Mackenzie Delta, western Arctic Canada. - Journal of Quaternary Science, 8/3: 185-196; Chichester.

Murton, J.B., Worsley, P. \& GozdziK, J. (2000): Sand veins and wedges in cold aeolian environments. - Quaternary Science Reviews, 19: 899-922; Amsterdam.

Møller Hansen, K., Brinch Petersen, E. \& Aaris-Sørensen, K. (2004): Filling the gap: Early Preboreal Maglemose elk deposits at Lundby, Sjælland, DK - Late Glacial hunters in transition. - In: Terberger, T./ Eriksen, B.V. (eds.): Hunters in a changing world. UISPP commission XXXII, Workshop Greifswald September 2002. Internationale Archäologie - Arbeitsgemeinschaft, Tagung Symposium, Kongress, 5: 75-84 ; Rahden/ Westf.

Pelegrin, L.J. (2000): Les techniques de débitage laminaire au Tardiglaciaire: critères de diagnose et quelques réflexions. - In: Valentin, B., Bodu, P. \& Christensen, M. (eds.): L'Europe centrale et septentrionale au Tardiglaciaire. Confrontation des modèles 
régionaux de peuplement. Mémoires du Musée Préhistoire d'Ile de France, 7: 73-86; Nemours.

Ralska-Jasiewiczowa, M., Goslar, T., RóŽAnsKi, K., WACNIK, A., CZernik, J. \& Chróst, L. (2003): Very fast environmental changes at the Pleistocene/ Holocene boundary, recorded in laminated sediments of Lake Gościąž, Poland. - Palaeogegraphy, Palaeoclimatology, Palaeoecology 193: 225247;

Reuter, G. (1990): Disharmonische Bodenentwicklung auf glaziären Sedimenten unter dem Einfluß der postglazialen Klima- und Vegetationsentwicklung in Mitteleuropa.Ernst-Schlichting-Gedächtniskolloquium: 69-74; Hohenheim.

Rother, H. (2003): Die jungquartäre Landschaftsgenese des Nebeltales im Bereich der Pommerschen Hauptendmoräne bei Kuchelmiß (Mecklenburg). - Greifswalder Geographische Arbeiten, 29: 93-129; Greifswald.

Rust, A. (1937): Das altsteinzeitlichen Renbtierjägerlager Meiendorf; Neumünster.

Rust, A. (1943): Die alt- und mittelsteinzeitlichen Funde von Stellmoor; Neumünster.

Schild, R. (2001): Three reasons why it is unlikley that the early Mesolithic population in Poland was not aboriginal. - In: Problems of the Stone age in the old world. Jubilee book for J.K. Kozlowski: 229-233; Kraków.

SCHIRMER, W. (1999): Dune phases and soils in the European sand belt. - GeoArchaeoRhein, 3: 11-42; Münster.

SснӧNHALs, E. (1944): Jungglazialer Löß auf Rügen. - Berichte des Reichsamtes für Bodenforschung, 4: 45-49; Berlin.

Schwabedissen, H. (1957): Das Alter der Federmesser-Zivilisation auf Grund neuer naturwissenschaftlicher Untersuchungen.Eiszeitalter und Gegenwart, 8: 200-209; Öhringen.

Seeler, A. (1962): Beiträge zur Morpholo- gie norddeutscher Dünengebiete und zur Darstellung des Dünenreliefs in topographischen Karten. - Diss. Univ. Greifswald; Greifswald.

Serangeli, J. (2003): La zone côtière et son rôle dans les comportments alimentaires des chasseurs-cueilleurs du paléolithique supérieur. - In: Patou-Mathis, M. \& BoCHERENS, H. (eds.): Le rôle de l'environment dans le comportments des chasseurs-cueilleurs préhistoriques. - British Arch. Reprots Int. Ser., 1105: 67-82; Oxford.

Sørensen, M. \& STERnKe, F. (2004): Nørregård VI - Late Glacial hunters in transition. - In: Terberger, T. \& Eriksen, B.V. (eds.), Hunters in a changing world. UISPP commission XXXII, Workshop Greifswald September 2002. Internationale Archäologie - Arbeitsgemeinschaft, Tagung Symposium, Kongress, 5: 85-112; Rahden/ Westf.

Staesche, U. (1994): Die Tierreste aus den Buntsandsteinabris im Leinebergland bei Göttingen. - In: Grote, K.: Die Abris im südlichen Leinebergland bei Göttingen. Archäologische Befunde zum Leben unter Felsschutzdächern in urgeschichtlicher Zeit II. Naturwissenschaftlicher Teil.- Veröffentlichungen der urgeschichtlichen Sammlungen des Landesmuseums Hannover, 43: 101-126; Oldenburg.

Street, M. (1996): The Late Glacial Faunal Assemblage from Endingen, Lkr. Nordvorpommern. - Archäologisches Korrespondenzblatt, 26: 33-42; Mainz.

Street, M., BaAles M. \& Weninger, B. (1994): Absolute Chronologie des späten Paläolithikums und des Frühmesolithikums im nördlichen Rheinland. - Archäologisches Korrespondenzblatt, 24: 1-28; Mainz.

Taute, W. (1968): Die Stielspitzen-Gruppen im nördlichen Mitteleuropa. - Fundamenta, A5; Köln, Graz.

Terberger, T. (1996a): Die „Riesenhirschfundstelle" von Endingen, Lkr. Nordvor- 
pommern. Spätglaziale Besiedlungsspuren in Nordostdeutschland. - Archäologisches Korrespondenzblatt, 26: 13-32; Mainz.

Terberger, T. (1996b): The Early Settlement of Northeast Germany (Mecklenburg-Vorpommern). - In: Larsson, L. (ed.), The Earliest Settlement of Scandinavia and its relationship with neighbouring areas. Acta Archaeologica Lundensia Series, 8/24: 111122; Stockholm.

Terberger, T. (1997): Zur ältesten Besiedlungsgeschichte Mecklenburg-Vorpommerns. - Archäologische Berichte aus Mecklenburg-Vorpommern, 4: 6-22; Waren.

Terberger, T. (1998): Grundwasserstände und spätpaläolithisch-mesolithische Besiedlung im Endinger Bruch. - In: Conard, N. \& KInd, C.-J. (eds.): Current Mesolithic research. Urgeschichtliche Materialhefte, 12: 89-102; Tübingen.

Terberger, T. (2002): Die retuschierten Formen. - In: Floss, H. \& Terberger, T.(Hrsg.): Die Steinartefakte des Magdalénien von Andernach (Mittelrhein). Tübinger Arbeiten zur Urgeschichte, 1; Rahden/Westf.

Terberger, T. (2004): The Younger DryasPreboreal transition in northern Germanyfacts and concepts in discussion. - In: TerBERgER, T. \& ERIKSEN, B.V. (eds.): Hunters in a changing world. UISPP commission XXXII, Workshop Greifswald September 2002. Internationale ArchäologieArbeitsgemeinschaft, Tagung Symposium, Kongress, 5: 203-222; Rahden/Westf.

Terberger, T. \& Lübke, H. (2004): Hamburger Kultur in Mecklenburg-Vorpommern? - Jahrbuch Bodendenkmalpflege Mecklenburg-Vorpommern, 52, Jahrbuch 2004: 15-34; Greifswald.

Theuerkauf, M. (2003): Die Vegetation NODeutschlands vor und nach dem Ausbruch des Laacher See-Vulkans (12880 cal. BP).Greifswalder Geographische Arbeiten, 29:

\section{1-175; Greifswald.}

Tromnau, G. (1975): Neue Ausgrabungen im Ahrensburger Tunneltal. Offa-Bücher, 33; Neumünster.

Usinger, H. (1985): Pollenstratigraphische, vegetations- und klimageschichtliche Gliederung des „Bölling-Alleröd Komplexes“ in Schleswig-Holstein und ihre Bedeutung für die Spätglazial-Stratigraphie in benachbarten Gebieten. - Flora, 177: 1-43;

Usinger, H. (1997): Pollenanlytische Datierung spätpaläolithischer Fundschichten bei Ahrenshöft, Kr. Nordfriesland. Archäologische Nachrichten aus Schleswig-Holstein, 8: 50-73; Schleswig.

VANDenberghe, J. (1988): Cryoturbations.In: Clark, M.J. (ed.): Advances in Periglacial Geomorphology: 179-198; Chichester.

VAN Der Hammen, T. (1957): The stratigraphy of the Late-Glacial. - Geologie en Mijnbouw, 19: 250-254; Utrecht.

VAN GeEL, B. (1996): Factors influencing changing AP/NAP ratios in NW-Europe during the Late-Glacial period. - Il Quaternario, 9: 599-604;

Van Geel, B., Bohncke, S.J.P. \& Dee, H. (1981): A palaeoecological study of an upper Late Glacial and Holocene sequence from "De Borchert", The Netherlands. - Review of Palaeobotany and Palynology, 31: 367-448; Amsterdam.

Van Geel, B., Coope, G.R. \& Van der Hammen, T. (1989): Palaeoecology and stratigraphy of the lateglacial type section at Usselo (The Netherlands). - Review of Palaeobotany and Palynology, 60: 25-129; Amsterdam.

Vang Petersen, P. \& L. Johansen (1996): Tracking Late Glacial Reindeer Hunters in Eastern Denmark. - In: LaRsson, L. (ed.): The Earliest Settlement of Scandinavia and ith relationship with neighbouring areas.Acta Archaeologica Lundensia Series, 8/24: 61-74; Stockholm. 